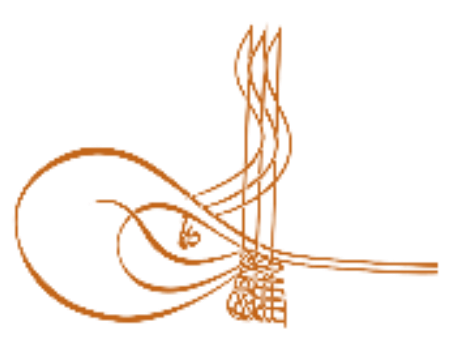

www.turkishstudies.net/turkishstudies

\section{Turkish Studies}

eISSN: $1308-2140$

Research Article / Araștırma Makalesi

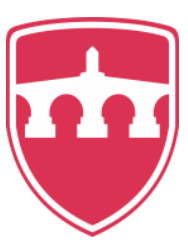

INTERNATIONAL

BALKAN

UNIVERSITY

Sponsored by IBU

\title{
18. Yüzyılda Tuna Donanması ve Donatımı
}

The Danube Navy in the 18th Century and Equipment

\author{
Mehmet Taş*
}

\begin{abstract}
The Danube fleet is one of the Ottoman State's navies operating in rivers. Besides the navy operating in the Ottoman Empire, it had another navy operating in rivers such as Aras, Furat, Şat, Özü, Nil and Tuna. This navy, was one of the main reasons that Ottoman domination gained stability on the lands where the rivers mentioned. This navy also called the thin fleet, played important roles both in carrying the weight of the land army during expeditions, in the worship and reinforcement of the original army during the war, and in fighting against the enemy navy using these rivers. As a result of these military-qualified missions, elements that create security risks for the state have been eliminated, piracy activities have been prevented and rivers have become safe waterways for trade and civil transportation. As civilian river transport develops, as a natural consequence of this, economic and commercial life has developed in the cities around the rivers mentioned. In this regard, one of the fine naval elements operating in the Ottoman rivers is the Danube navy. Danube navy, named after the Danube river, where it operates, played an important role in the establishment, strengthening and maintenance of Ottoman rule in the Balkans. He has contributed to many important conquest movements, including the conquest of Belgrade in the Balkans. In an environment where wars with Austria and Russia in the Balkans increased in the 18th century, the Danube fleet had an important role in the Ottoman Empire's holding in this geography. Even if there is more or less information about the activities of the Danube fleet, there is not much information about the elements that compose it with a logistic perspective. In fact, this navy is made up of a large network of intertwined relationships and concepts, ranging from crew to shipbuilding, from skilled labor to financing. There were unique shipyards where this navy was built, ships built according to the characteristics of the Danube river in these shipyards, skilled workers working in the construction of these ships, and a financial background that met their expenses. Understanding them will provide a better understanding of the existence of the Ottomans in the Balkans.
\end{abstract}

Structured Abstract: The Ottoman State is a world state that ruled over three seas, consisting of Asia, Europe and Africa, and many seas such as the Mediterranean, the Black Sea, the Red Sea and the Adriatic sea. Although this state was established in Anatolia, it spread in Europe in a short time and succeeded in including the Middle East and North Africa in its field in a short time. Undoubtedly, his military strength is one of the factors affecting his success. One of the elements that make up its military power is the land army

\footnotetext{
* Dr, Hatay İl Milli Eğitim Müdürlüğü

Ph.D., Hatay Provincial Directorate of National Education

ORCID 0000-0003-1794-9629

mehmet-tas@msn.com

Cite as/ Atıf: Taş, M. (2020). 18. Yüzy1lda Tuna Donanmas1 ve donatımı, Turkish Studies, 15(2), 1399-1418.

https://dx.doi.org/10.29228/TurkishStudies.39483

Received/Geliş: 26 October/Ekim 2019

Accepted/Kabul: 25 April/Nisan 2020

Copyright (C) MDE, Turkey

Checked by plagiarism software

Published/Yayın: 30 April/Nisan 2020

CC BY-NC 4.0
} 
and the other is the navy that operates in the sea, lakes and rivers. Therefore, the Ottoman navy played a major role in the growth and expansion of the Ottoman State.

The logistic base and main headquarters of the Ottoman navy is Tersane-i Âmire in Istanbul. This is an important place where both new warships are built and the navy is dispatched and administered. The navy consisting of the ships built here is known as the Istanbul navy. The Istanbul navy is just one of the navies that make up the Ottoman navy along with the Umrah-yi derya navy, the west principalities navy and the thin navy. The thin fleet consists of combinations of different war fleets, such as the Danube, Euphrates, Tigris and Nile fleets.

After the Ottoman Empire passed to the Balkans in 1353, it did not delay in realizing the military, political and commercial importance of the Danube River. The flow basin of the river made it easier for it to advance in the Balkans and has managed to become an important military force of Europe by advancing to Central Europe. Kili created its own cruise and usage regime in the Danube River after the conquest of cities in the river basin of the Danube, such as Ibrail, Akkirman, Silistra, Rahova, Varna and Belgrade.

The Ottomans used the Danube River for the transportation of soldiers, supplies and ammunition in the European campaigns of the land army, for the fortification of important castles such as Belgrade, Fethülislam, Nis and Silistra, for the construction of Istanbul and for commercial purposes. Accordingly, they have created shipyards in certain accidents, and they have built shayka, skirmish, quality, and tombas-type ships capable of swimming in the Danube river. For the safe passage on the river, they created a Vortex Tree and appointed officers for a fee. This use of the Danube River is in line with the use of the Roman and Byzantine Empire, which had ruled the Balkans before the Ottomans. They also used the Danube River for the same purposes and similar methods. There is no doubt that the Ottomans took advantage of their experience.

The materials needed for the construction and equipment of the Danube Navy and qualified workforce were tried to be met primarily from accidents adjacent to the Danube River. When this was not enough, the resources of central public institutions such as Tersane-i Âmire, Tophane-i Âmire or Cebehane-i Âmire were mobilized. In fact, the demands of the Danube Navy were not rejected by Istanbul due to its importance, and utmost care was taken to meet its needs. Due to the centralist structure of the Ottoman administration, important decisions regarding the Danube fleet were made from Istanbul.

Despite the efforts of the central and provincial administrators in the construction and equipment of the Danube Navy, the problems were not lacking. At the beginning of these problems are insufficient income sources, inadequate supply of equipment materials, and inadequate control of the ship's crew. The large number of wars with foreign states and domestic problems in the 18th century further increased these problems. However, these problems were not ignored by the central government and were addressed to solve them. Although it is not possible to say that these problems have been solved completely, it can be said that the system, which worked slowly, provided the Ottoman State to remain an effective power in the Danube river until the end of the 18th century.

Keywords: Thin navy, Balkans, 18th Century, Ottoman Empire, Danube River.

Öz: Tuna donanması, Osmanlı Devleti'nin nehirlerde faaliyet gösteren donanmalarından birisidir. Osmanlı Devleti denizlerde faaliyet gösteren donanmasının yanında Aras, Fırat, Şat, Özü, Nil ve Tuna gibi nehirlerde faaliyet gösteren başka bir donanmaya sahipti. Bu donanma, Osmanlı hâkimiyetinin adı geçen nehirlerin bulunduğu topraklar üzerinde istikrar kazanmasının ana nedenlerinden birisiydi. İnce donanma olarak da isimlendirilen bu donanma, gerek seferler sırasında kara ordusunun ağırlıklarının taşınması, gerek savaş sırasında asıl ordunun ibate ve takviyesinde ve gerekse de bu nehirleri kullanan düşman donanmalarıyla mücadele etmekte önemli görevler ifa etmekteydi. Askeri nitelikli bu görevleri sonucunda hem devlet açısından güvenlik riski oluşturan unsurlar bertaraf edilmiş, hem korsanlık faaliyetlerinin önüne geçilmiş hem de bu sayede nehirler ticaret ve sivil ulaşım için güvenli suyolları haline gelmiştir. Sivil amaçlı nehir taşımacılığ 1 geliştikçe ise bunun doğal bir sonucu olarak adı geçen nehirlerin çevresinde bulunan şehirlerde, iktisadi ve ticari hayat gelişmiştir. $\mathrm{Bu}$ minvalde, Osmanlı nehirlerinde faaliyet gösteren ince donanma unsurlarından bir tanesi de Tuna donanmasıdır. Adını faaliyet gösterdiği Tuna nehrinden alan bu donanma, Balkanlarda Osmanlı hâkimiyetinin kurulması, güçlenmesi ve sürdürülmesinde önemli roller oynamıştır. Balkanlarda gerçekleşen Belgrad'ın fethi dâhil birçok önemli fetih hareketinde onun katkısı vardır. 18. 
yüzyılda Balkanlarda Avusturya ve Rusya ile yapılan savaşların arttığı bir ortamda, Osmanlı Devleti'nin bu coğrafyada tutunmasında yine Tuna donanmasının önemli bir rolü olmuştur. Tuna donanmasının faaliyetleri hakkında az çok kaynaklarda bilgi bulunsa bile lojistik eksenli bir bakış açısıyla onu oluşturan unsurlar hakkında kaynaklarda fazla bilgi yoktur. Esasında bu donanma, mürettebatın iaşesinden gemilerin inşasına, nitelikli işgücünden finansmana kadar geniş bir yelpazede çok sayıda iç içe geçmiş ilişkiler ve kavramlar ağından oluşmaktadır. Bu donanmanın inşa edilmiş olduğu kendine has tersaneler, bu tersanelerde Tuna nehrinin özelliklerine göre inşa edilmiş olan gemiler, bu gemilerin inşasında çalışan nitelikli işçiler ve bunların masraflarını karşılayan bir mali arka plan bulunmaktaydı. Bunların anlaşılması Osmanlıların Balkanlardaki varlığının daha iyi anlaşılmasını sağlayacaktır.

Anahtar Kelimeler: İnce donanma, Balkanlar, 18. yüzyıl, Osmanlı Devleti.

\section{Giriş}

Tuna Nehri, Almanya'da Karaorman Bölgesi'nden doğup Karadeniz’e dökülen 2860 km uzunluğunda bir nehirdir. $\mathrm{Bu}$ nehir konumu ve işlevi dolayısıyla tarih boyunca Avrupa ve Balkanlar tarihinde önemli bir yere sahip olmuştur. Orta Avrupa'nın ham madde, tarımsal ürünler, tuz ve canlı hayvan gibi ticari ürünlerinin Karadeniz havzasına taşımasının yanında Anadolu, Kafkasya ve Kırım'da üretilen pamuklular, ipekliler, çuha, halı, ipek, zeytin ve turunçgil gibi mamul, yarı mamul ürünlerin Avrupa ülkelerine ulaştırılmasında bir kanal işlevi görmüştür. (Gümüş, 2016:36). Avrupa'nın en uzun bu ikinci nehri, Balkanlar, Anadolu, Kafkasya ve Kırım'ın ticari anlamda Avrupa ile bütünleşmesinde önemli bir rolü olmuştur. Tuna Nehri ticari öneminin ötesinde siyasi ve askeri anlamda Avrupalı güçlerin Avrupa'nın güneydoğusuna yayılmasında etkili olurken Avrupa dışı güçlerin de Avrupa'ya doğru genişlemesinde bir köprü işlevi görmüştür. Bu güçler Tuna Nehri havzası boyunca doğu ya da batı istikametinde ilerlemişlerdir.

Osmanlı Devleti, 1353 yılında Rumeli'ye geçtikten sonra fetihlerin yönü Avrupa'ya dönmüş ve bir süre sonra Tuna Nehri ile onun yolları kesişmiştir. Yıldırım Bayezid (1389/1402) döneminde 1395 'te Niğbolu'nun fethi ile Rumeli'den Eflak'a kadar olan bölgede Tuna Nehri üzerindeki geçitlerin birçoğu kontrol altına alınmıştır. Bu tarihten itibaren Osmanlılar, 150 yıl içinde Vidin, Lom, Rahova, Ziştovi, Rusçuk, Tutrakan, Silistre, Boğazköy, Hırsova, Maçin, Potbaşi, Tulçı, Sünne ve kuzeyindeki Kalafat, Turnu, Magurele, Zemniça, Yergöğü, Oltenitza, Kalaraşi, İbrail, Kalas, İsmail ve Kili gibi şehirleri de kendi topraklarına katarak, Tuna Nehri'nin Karadeniz'e dökülen aşağı kısmında uzun sürecek bir hâkimiyet kurmuşlardır. Bu hâkimiyetin neticesinde nehrin kullanım rejimi Türklerin lehine tamamen değişmiş, Orta ve Aşağ 1 Tuna'da Osmanlı Devleti'nin izin ve ruhsatı dışında gemi yüzdürmek imkânsız hale gelmiştir. Ancak 1699 Karlofça Anlaşması'yla Avrupa ve Osmanlı devleti arasındaki değişen güç dengelerine paralel şekilde Tuna Nehri'nin kullanım rejimi de değişmeye başlamıştır. (Pul,2014:286). Bu anlaşmayla Morş ve Tizsa sularında Avusturya Devleti'nin gemileri serbest dolaşım hakkını elde etmiş, 1718 Pasarofça Anlaşması ile de Tuna'daki Vidin, Rusçuk gibi limanlara Avusturyalıların kendi gemileriyle gelebilme hakkı karar altına alınmıştır. Bu durum hem Avusturya'nın aşağı Tuna ticaretine dâhil olmasına hem de İngiltere ve Fransa gibi küresel aktörlerin ilgilerinin buraya yönelmesine sebep olmuştur. Bu son iki devlet 1740'tan sonra Tuna Nehri'nde serbest ticaret rejimin hâkim olması için çalışmaya başlamışlardır. (Gümüş, 2014:38).

18. yüzyılın ikinci yarısında yaşanan Osmanlı-Rus savaşlarında Aşağı Tuna bu iki devletin kara ve deniz güçlerinin mücadelesine sahne olmuştur. 1768-1774 Osmanlı-Rus Savaşı'nda, 1770 Kartal yenilgisinden sonra Bender ve İsmail kaleleri ve ardından Bucak Bölgesi (Kili, İbrail, Akkirman) Rusların eline geçmiştir. Savaş sırasında Rusların ele geçirdiği bu kaleler 1774 Küçük Kaynarca Anlaşması'yla yeniden Osmanlı'ya iade edilmişse de savaşın Tuna hattı üzerinde gerçekleşmesi Osmanlı Devleti'nin buradaki kalelerin tamiri ve tahkimine önem vermesine sebep olmuştur. Özellikle 1774 Küçük Kaynarca Anlaşması'ndan sonra Tuna üzerindeki birçok kale yenilenerek, istihkâmlar yapılmaya başlanmıştır. Osmanlı Devleti'nin önce Rusya ile başlayan 
ardından Avusturya'nın da dâhil olduğu 1787-1792 Savaşı'nda bölge yeniden Osmanli-Rus mücadelesine sahne olmuş ve Ruslar, 1789'da Akkirman'1 almışlardır. 1790 yılında Tuna Nehri'nin önemli kazalarından Kili ve ardından Sünne, Tolcu, İsakçı ve İsmail Rusların eline geçmiştir. (Gümüş, 2014:39).

Tuna Nehri, Osmanlı ordusunun Avrupa seferlerinde taşımacılıkta sıkça kullandığı bir nehirdir. Tuna Nehri'nin kara ordusunun takviyesi için kullanılması ilk defa Fatih Sultan Mehmet (1451-181) döneminde başlamış, Kanuni Sultan Süleyman (1520-1566) döneminde Macaristan'ın fethi ile Tuna Nehri'nde müstakil bir donanma yapılmış ve Tuna Kaptanlığı meydana getirilmiştir. Tuna Kaptanlığı ise iki bölgeye ayrılmış olup biri Vidin'e kadar bölgeyi kapsarken diğeri Vidin'den Budin'e kadar bölgeyi kapsamaktaydı. Gerek Tuna ve gerekse de Tuna'ya dökülen nehirlerde işleyen gemi ve kayıklarla bunların kaptanları, bu iki Tuna kaptanının emir ve gözetimi altında bulunmaktaydı. Her bölge kaptanının emri altında 10 firkate ile 1000 kadar bahriye azabı vardı. Macaristan'ın elden çıkmasıyla Tuna kaptanlığı bire düşmüştür. 17. yüzyıl sonlarında Silistre'den Belgrat'a kadar Tuna sahillerinde 12 adet ocaklık şayka ile kaptan bulunmaktaydı. (Uzunçarş111, 1988:403).

Tuna Nehri, Osmanlı Devleti açısından sadece taşımacılık yönünden değil, askerî ve güvenlik nedenleriyle de önem arz etmekteydi. Askeri nedenlerin başında ise Orta Avrupa'da yapılacak fetihler için bu nehrin önemli bir konuma sahip olması gelmekteydi. $\mathrm{Bu}$ nehir kullanılmak suretiyle Osmanlı kara ordusunun nakliye, takviye ve iaşesi temin edilebilmekte hatta Osmanlı hâkimiyeti için önem taşıyan kale ve şehirlere yardım ulaştırılabilmekteydi. Balkan coğrafyasının yüksek dağlar ve derin vadilerden oluşan engebeli coğrafyası, kara yoluyla askerlerin naklini meşakkatli ve masraflı hale getirmekteydi. Nehir yoluyla yapılan askerî nakliyat ise daha ucuz ve daha hızlıydı. Ayrıca Osmanlı ordusunun doğu yönünde yaptığı seferler sırasında ihtiyaç duyulan buğday ve erzakın bir kısmı Eflak'tan tedarik edilmekte, daha sonra da Tuna Nehri'nden gemilerle Varna, Silistre ve Karadeniz'e ulaştırılmakta, buradan ise Trabzon'a taşınarak arabalar vasıtasıyla orduya yetiştirilmekteydi. Yine İstanbul'un hububat ambarı haline gelmiş Boğdan ve Eflak eyaletlerinin buğdayı Tuna Nehri'nde işleyen gemiler vasıtasıyla İstanbul'a taşınmaktaydı. $\mathrm{Bu}$ nehir üzerinde bulunan adaların ve bizatihi nehrin güvenliği, Osmanlı Devleti'nin ülke savunması için önem taşımaktaydı. Tuna Nehri'nin hâkimiyetini ele geçirecek herhangi bir düşman güç, Balkanlarda bulunan birçok önemli Osmanlı şehrini kontrolü altına alabileceği gibi Karadeniz'deki Türk hâkimiyetini ve İstanbul'un güvenliğini tehdit edebilirdi. 1396 Niğbolu Savaşı ve 1444 Varna Savaşı (Emecen, 2012:528) bunu kanıtlamıştı. (Emecen, 2007:90) Dolayısıyla bu nehirde hâkimiyetin korunması için nehrin coğrafi ve fiziksel özelliklerine uygun gemilerin yapımına ayrı bir önem verilmiştir. Gemi yapımına verilen öneminin sonucu olarak, çok sayıda askeri amaçlı savaş ve nakliye gemisi inşa edilmiştir. Nehir boyunca seyahat eden diplomat ve gezginler bunu seyahat notlarında ifade etmişlerdir. Örneğin Stefan Gerlach, mühimmat yüklü 60 büyük gemiden bahsetmektedir. Ondan sonraki y1llarda Avusturyalı diplomat Johann von Kindsberg'in İshakçı'da kaldığı sürece tuttuğu notlarda da 200 büyük gemiden ve yanlarında nakliye için kullanılan kayıklardan söz edilmektedir. (Pul, 2014:288).

\section{Tuna Nehri'nde Kullanılan Gemiler}

Tuna Nehri'nde kullanılan gemilerin türleri Akdeniz ve Karadeniz'de kullanılan gemilerden farklılık arz etmekteydi. Her şeyden önce bu gemiler yapı olarak nehrin yatak ve debi özelliklerine uygun olarak tasarlanmış gemilerdi. Çünkü bu nehrin sularının bazı dönemlerde çekilmesi ya da bazı dönemlerde taşması sonucunda, ağır tonajlı gemiler için karaya oturma, batma, hasar görme ya da kıyıya yanaşamama gibi sorunlar ortaya çıkmaktaydı. Normalde akış1 son derece hızlı olan bu nehrin yatağı tehlikeli kayalıklarla kaplanmış olduğu için bazı yerlerinde girdaplar oluşmaktaydı. Bu girdaplar Belgrat yakınlarındaki Demirkapı olarak isimlendirilen yerde yoğunlaşmaktaydı. Girdaplardan geçiş esnasında gemilerin kayalıklara çarpmasını engellemek amacıyla yeterli miktarda yük boşaltılarak arabalarla veya üstüaçık türü gemilere aktarılarak nehrin 
yukarı kısımlarına taşınmaktaydı. Vakanüvist Subhi Mehmet Efendi, bu girdapların boyunun bir kale burcu boyuna çıktığını ve Tuna Nehri'nin bir deniz kadar derin olduğunu bildirmektedir. (Subhi Mehmet Efendi, 2007:471). Devlet burası için bir görevli tayin etmişti. Girdaplar bölgesinden geçecek zahire ve mühimmat gemilerinin her türlü güvenliğini sağlamakla görevli kişinin unvanı Girdap Ağası'ydı. Onun bağlı olduğu kişi ise Tuna Kaptanı'ydı. (Pul, 2014:293). Akıntıya ters istikamette seyrederken kürekler fayda vermemekte, yelkenler de hiç kullanılamamaktaydı. (Pul, 2014:289). Tuna Nehri'nde kullanılan gemilerin başında şayka türü gemiler gelmekteydi. Şayka türü küçük tonajlı gemiler hız ve hareket kabiliyeti bakımından büyük ebatlı olanlara göre daha kullanışlıydı. Çünkü gece gündüz her türlü hava şartlarında yol alabilmekte ve istenilen yerde karaya yanaşabilmekteydiler. Kalyon türü büyük tonajlı gemiler ise hem bunları yapamamakta hem de devrilme tehlikesi göstermekteydiler. Bu yüzden büyük tonajlı gemiler Tuna Nehri'nde daha çok hububat naklinde kullanılmaktaydılar. (Pul, 2014:291). Belirtilen nedenlerle bu nehirde görev yapacak gemiler inşa edilirken, kereste dâhil yapım malzemelerinin özenle seçilmesi gerekmekteydi. Gemiler inşa edildikten sonra ise nehri iyi bilen bilgili ve tecrübeli kaptan ve dümenciler tarafından idare edilmesi lazımdı.

Osmanlı Devleti'nde Tuna donanmasına ait gemiler, Rahva, Ziştovi, Silistre, Rusçuk, Niğbolu ve Vidin gibi şehirlerde bulunan tersaneler de inşa edilirken ${ }^{1}$; Güvercinlik, Semendire, Belgrad, İzvornik, Alacahisar, Pojego, Mohaç, Budin ve Estergon'da da küçük gemi inşa tezgâhları kurulmuştur. (Pul, 2014:302). Tuna Nehri'nde görev yapan gemilerin başında şayka, firkate $^{2}$, kalyete ${ }^{3}$, şalopa, üstüaçık ${ }^{4}$ ve tombaz gelmektedir ${ }^{5}$.

\subsection{Firkate}

Firkateler uzun ve dar gemiler olup hem kürekle hem de yelkenle hareket edebilmektedir. Ancak asıl hareket kaynağı yelken değil insanların çektiği küreklerdir. Her küreğini iki üç kişinin çektiği firkateler, aynı zamanda ince donanma sınıfından oldukları için nehirlerde de kullanılabilmekte ve hızlı hareket kabiliyetleri dolayısıyla haberleşmede bile kullanılabilmektedir. Firkateler 10-17 oturağa sahiptir. (Bostan, 2010:227-228). Tuna Nehri'nde görev yapan firkatelerde 18. yüzyılda 80 kadar levent olup her bir firkateye 3,000 kuruş yıllık ücret verilmekteydi. Bu firkatelerde görev yapan her asker 37,5 kuruş ücret almaktaydı. Bu ücretin diğer nehirlerde görev yapan firkate askerlerinin ücretiyle aynı olduğu anlaşılmaktadır. Örneğin aynı dönemde Fırat Nehri donanması için Birecik'te inşa olunan 60 firkatenin her birinde 70 levent olup her firkateye yıllık 2,625 kuruş ödenmişti. Yani levent başına yıllık 37,5 kuruş ücret düşmekteydi ${ }^{6}$.

\subsection{Kalyete}

Kalyete türü gemiler, isim olarak Mehmet Zeki Pakalın'da "kalite”, (Pakalın, 1983:151) İdris Bostan'da ise "Kalyata" olarak geçmektedir. (Bostan, 2010:126). İtalyanlar bu gemiye

\footnotetext{
1 Tuna Kaptanı el-Hac Memişzade'ye hitaben 3 Cemaziyülevvel 1203 (30 Ocak 1789) tarihinde yazılan hükümde, hazırlanmış olan 34 kadar çete kayığından 10 tanesinin Vidin, 3 tanesinin Rahva, 5 tanesinin Niğbolu, 4 tanesinin Ziştovi, 6 tanesinin Rusçuk ve 6 tanesinin Silistre'de hazırlanmış olduğu bildirilmiştir. (bk. BOA.C.BH.197.9242.1.)

${ }^{2}$ BOA.IE.BH.10.908.1.1.

${ }^{3}$ BOA.IE.BH.6.504.1.1.

${ }^{4}$ Tuna kaptanı olarak atanan Mehmet'e yazılan bir hükümde ondan şayka, kalyete ve üstü açık gemiler ile diğer donanma gemilerinin takımlarını yoklayıp önceki kaptanın muhasebesini görüp, eğer gemi leventlerinin ücretleri ya da sair malzeme ve mühimmattan zimmetinde bir nesne kalmışsa bunu tahsil etmesi ve emrindeki gemileri donatması istenmektedir. (bk. BOA.A.DVNS.MHM.d.106.128. )

${ }^{5}$ Bosna valisi tarafindan inşa olunan tombaz arabaları malzemesi için Tersane-i Âmire'den talep edilen 1000 adet palamarın İsakçı İskelesi'ne gönderileceğine dair 12 Muharrem 1183 (18 Mayıs 1769) tarihli arz için bk. BOA.C.BH.202.9453.1.1.

${ }^{6}$ Birecik'teki firkatelerin asker yönünden eksiği olduğu görülmüş ve gemi sürmeye vakıf 32 askerin İstanbul'dan gönderilmesine karar verilmişti. İnce donanma gemilerinde çalışacak mürettebat görev yapacakları gemiye ulaşmak için ilgili iskeleden gemiye binip yol almaya başladıkları andan itibaren altı ay sonra yıllık ücretlerini almaya hak kazanmaktaydılar. (bk. BOA.İE.BH.10.908.1.1.)
} 
"galita", Fransızlar "galiota", İngilizler ise "galyot" ismini vermişlerdir. Bu gemiler 18. yüzyılda 25 m uzunluğunda olup 20-24 oturağa sahiptir. (Pakalın, 1983:151). Bu gemiler olağan askeri amaçların dışında takip ve haberleşme hizmetinde de kullanılmaktaydı. (Bostan, 2010:126). Kalyeteler, 18. yüzyılda Tuna Nehri'nde kullanılmış gemi türlerinden birisiydi. 8 Şubat 1694 tarihinde miri kalyonlarda görev yapan ve ücretini kışlada iken almış olan bazı leventlerin Tuna donanmasındaki kalyetelere levent olarak yazıldığı bildirilmekte ve bu durumun kalyonlarda mürettebat sıkıntısına yol açtığından bahsedilmektedir? ${ }^{7}$.

\section{3. Şalopa}

Şalopa türü gemiler küçük yelkenli ve ambarsız gemilerdi. Şalopaların 18. yüzyılın sonlarına doğru Osmanlı donanmasında kullanılmaya başlandığı anlaşılmaktadır. 1787'de Tersanei Âmire'de yapılması kararlaştırılan 20 kadar şalopadan anlaşıldığ kadarıyla 10 tanesinin uzunluğu 17 m iken diğer 10 tanesinin uzunluğu 14,8 m idi. (Bostan, 2010:169). Tuna Nehri'ndeki ince donanma saflarında görev yapan şalopalar bazen nehrin akış debisinin yüksek olması sebebiyle çabuk yıpranmakta ve tamire muhtaç hale gelmekteydi. Bu iş için İbrail şehri yakınlarındaki Salhane Adası onların tamir amacıyla çekildiği yerlerin başında bulunmaktaydı ${ }^{8}$.

\section{4. Şayka}

Şayka türü gemiler, altı düz ve enli olup Tuna Nehri dışında Dinyeper ve Özi nehirlerinde de kullanılmıştır. Osmanlıların dışında Kazaklar ${ }^{9}$ tarafından da bu gemilerin kullanılmış olması bu gemilerin yapısı itibarıyla nehirlerde kullanılmaya müsait olduğunu göstermektedir. 18. yüzyıla kadar şaykaların ortalama uzunlukları 13-25 m arasında değiştiği halde aynı yüzyılda daha uzunları yapılmaya başlanmıştır. Yelken yanında kürekle hareket edebilen bu gemilerin kürekçi sayısının savaş durumunda farklı, barış durumunda farklı olduğu anlaşılmaktadır. Örneğin Rusçuk kaptanının şaykasında, barış zamanında 18, sefer sırasında ise 24 kürekçi bulunmaktaydı. 18. yüzyılda Silistre kaptanının şaykasında 30, Fethülislam Kaptanı'nın şaykasında 40 ve Vidin Kaptanı'nın şaykasında 33 kürekçi bulunmaktaydı. (Bostan, 2010:132-133). Şayka kaptanları senelik 118 kuruş ücret alırken topçu, dümenci ve kürekçilerin her biri 25 kuruş ücret almaktayd ${ }^{10}$.

Şaykalar, şayka inşası için ocaklık olarak tayin edilen yerlerde inşa olunmaktaydı. Örneğin Niğbolu, Rusçuk, Silistre, Hırsova, İsakçı, İbrail, Kili, Fethülislam, Vidin ve Belgrat kazaları birer şaykayı ocaklık olarak hazırlamakla yükümlüydü. (Bostan, 2010:134). Bu kazalardaki "nazır” olarak isimlendirilen görevliler padişaha karşı bu konuda sorumluydular. 1688/1689 yılında Kili nazırından 2 adet şayka hazırlayarak Vidin muhafizı Hüseyin Paşa'ya teslim etmesi istenmişti ${ }^{11}$. Şaykalardaki dümenci, levent, kürekçi ve topçuların ücretleri ise yine ocaklık usulüyle ilgili kazaların gelirlerinden karşılanmakta idi ${ }^{12}$. Yine aynı şekilde bu şaykalarının tamir masrafları bu kazaların ocaklık gelirlerinden karşılamaktaydı. 4-5 yılda bir defa ise bu gemiler tamir edilmekteydi ${ }^{13}$. İstisnai durumlarda tamir masraflarını devlet karşılamaktayd $1^{14}$. Şayka inşası 18.

\footnotetext{
${ }^{7}$ Kalyete, firkate ve kalyon kaptanlarının birbirinin leventlerine mani olmayıp kalyonlarda olan leventler firkate ve kalyetelere yazılırsa daha önce aldıkları ücretin bu gemilerde alacaklarına mahsup edilmesi istenmektedir. (bk. BOA.İE.BH. 6.504.1.1. )

${ }^{8}$ BOA.C.BH.101.4875.3.1.

9 "Cossak" olarak kaynaklarda geçen ancak Kazak olarak Türkçe’ye yerleşen bu topluluğun Kazak Türkleriyle hiçbir ilgisi yoktur. Bunlar Lehistan Kralı Sigismund tarafından Lehistan'ın sınırlarını korunması amacıyla 1516 yılında teşkil edilmiş alaylardır. Bu alaylar Dinyeper Nehri kıyısına yerleştirilmişlerdir. Rusların da aynı isimde süvari alayları bulunmaktaydı. (bk. Mehmet Zeki Pakalın, Osmanlı Tarih Deyimleri ve Terimleri Sözlügüü, 3. Baskı, Cilt II, Milli Eğitim Basımevi, İstanbul, 1983, s. 228.)

${ }^{10}$ BOA.C.BH.267.12319.1.1.

${ }^{11}$ BOA.ADVNS.MHM.d.98.36. /Evahir Rebiyülahir 1110 (Ekim/Kasım 1698)

12 BOA.C.BH.267.12319.1.1.

${ }^{13}$ BOA.C.BH.247.11465.1.1. /12 Cemaziyülevvel 1203(8 Şubat 1789)
}

Turkish Studies, 15(2) 
yüzyıl sonlarına kadar devam etmiştir. 1784 yılında ise şayka inşası yasaklanmıştır. (Bostan, 2010:134). Şaykalar 16 karış boyunda ve $29 \mathrm{~kg}$ mermer gülleler atan toplar kullanmaktaydı. (Pakalın, 1983:312).

Şayka kaptanlarının 18. yüzyılda girdap ağalığı için atandığı anlaşılmaktadır. Örneğin 15 Eylül 1703 tarihinde İpek Şaykası kaptanı Yahya Kaptan atanmış olup kendisine bu hizmeti ifa edebilmesi amacıyla 30,000 adet kınnab (ince sicim) gönderilmiş, bunların masrafı olan 1092 kuruşun ise Eflak hazinesi malından karşılanmasına karar verilmiştir ${ }^{15}$. Şayka kaptanlarından birisine bu önemli görevin verilmiş olması, şaykaların Tuna Nehri'nde yaygın olarak kullanılması dolayısıyla onların bilgisine ve tecrübesine devlet tarafından duyulan güvene yorumlanabilir.

\section{5.Üstüaçık}

Üstüaçık türü gemiler daha çok nakliye işlerinde kullanılmakta olup 1 reis, 1 dümenci ve 8 kürekçiden oluşan mürettebat tarafından idare olunmaktaydı. (Bostan, 2010:136). Üstüaçıkların teçhiz ve tekmil ettirilmesinden sorumlu esas kişi ise Açılar Ağası'ydı. Bu unvan Tuna Nehri'nde işleyen ve açık gemiler adını taşıyan gemilerin işlerine bakan memurun unvanıydı. Açıklar Ağası zahire yüklü kayıkları, sağ salim şekilde Tuna'nın girdaplarından geçirmekle de yükümlüydü. (Pul, 2014:294). 1717 yılında Avusturya seferi için Tuna'ya sevk edilen ince donanmada 80 adet üstü açık bulunması planlandığından zaten mevcut olan 10 üstüaçıka ilave olarak 70 adet daha üstü açık yeniden inşa edilmiştir. (Bostan, 2010:137).

\subsection{Tombaz}

Tombaz türü gemiler hem kürekle hem de yelkenle hareket edebilen ve nehirlerde köprü dubası olarak kullanılan altı düz kayıklar olarak tarif edilmiştir. (Bostan, 2010:138). Bu gemilerin güvertesi yoktur. Tuna Nehri'nde nakliye ve köprü dubası olarak kullanılan bu gemilere tüccarlar da ihtiyaç duymaktaydı. Örneğin 1779 yılında Unkapanı tüccarlarından birisinin şikâyeti üzerine Yaylağan ve Sünne Boğazı taraflarına tombazların getirilmesi gerekmiştir. Çünkü Tuna Nehri'nin bu kısmında sular çekildiği için ağır tüccar gemilerinin adı geçen yerlerden geçmesi zorlaşmıştır. (Bostan, 2010:138). Salomon Schweigger ismindeki bir Protestan vaiz, Ova şehrinde Tuna Nehri üzerine inşa edilmiş bulunan ve 65 tombaza dayanan ahşap bir köprünün varlığından bahsetmektedir. (Schweigger, 2014:41). Bu bilgi tombazların köprü dubası olarak kullandığ1 hakkındaki bilgiyi doğrulamaktadır.

Yukarıda adı geçen gemiler kadar olmasa da kalyon sınıfı gemilerin de Tuna Nehri'nde kullanıldığ 1 anlaşılmaktadır. Çünkü 1769/1770 tarihinde Ebu Bekir Kaptan'a gönderilen bir hükümde Ağustos ayının on beşinden sonra Sünne Boğazı'nın sularının azalması sebebiyle kaptanı olduğu kalyonun ve diğer kalyonların geçişlerinde sorun yaşanacağı ve Tuna'ya memur olan bu kalyonlarla birlikte zamanında İstanbul'a dönmesi gerektiği ifade edilmektedir. Vakanüvist Suphi Mehmet Efendi de 1739/1740 tarihinde Avusturyal1lara ait 5 kalyonun Tuna Nehri'nde topla vurularak yara aldığından ve 3 tane düşman kalyonunun ise girdaplar bölgesinde yaşadıkları sorunlar nedeniyle Yukarı Belgrat tarafina gidemediğinden bahsetmektedir. (Suphi Mehmet Efendi, 2007:569). Kalyonların ağır tonajlı ve büyük bordalı gemiler oldukları düşünülecek olursa bu gemilerin daha çok Karadeniz kıyısından itibaren Belgrat yakınlarına kadar olan Aşağı Tuna'da hizmet verdikleri anlaşılmaktadır. Esasen Belgrat'tan daha yukarıda olan kısımlarda nehir yatağının yapısı ve debisi nedeniyle kalyonların kullanılması pek de mümkün değildir.

\footnotetext{
${ }^{14}$ Semendire şaykası kaptanı, kullanmış olduğu şaykanın eskimiş ve t Âmire muhtaç hale gelmiş olduğunu beyan ederek padişaha arzuhal göndermiş ve yardım istemiştir. Bunun üzerine kendisine 4 Recep 1204 (20 Mart 1790) tarihinde hazine tezkiresi verilerek 230 kuruş ödeme yapılmıştır. (bk. BOA.C.BH.211.9853.1.1. )

${ }^{15}$ BOA.C.BH.237.10986.1.1.
} 


\section{Gemilerin Donatımı}

Tuna donanmasının teçhiz ve donatımından Tuna kaptanı sorumluydu. O, gemileri ve kayıkları, “...mükemmel neferat ve zabitan ve takım ve levazımla istishab..." ile görevliydi ${ }^{16}$. Ayrıca Belgrat, Semendire, Rusçuk ve Varna gibi mühim kalelerin tamir ve tahkiminde emri altındaki gemilerle kereste, taş, kireç ve kum taşımak da onun göreviydi ${ }^{17}$. Dolayısıyla bu önemli göreve vezir rütbesine sahip ve bazen "dergâh-ı âli kapıcıbaşısı" ünvanlı kişiler atanmaktaydı. Genelde ise Tuna donanmasındaki gemilerin kaptanlarından birisi bu göreve tayin edilmekteydi. Atamada gözetilen ilke ise 1701 tarihli Bahriye Kanunnamesi'yle vurgulanan liyakat, bilgi ve beceriydi ${ }^{18}$. Tuna kaptanlarının asıl görevi, 18. yüzyılda Avusturya ve Rusya ile yoğunlaşan savaşlara paralel şekilde Tuna'nın; "avn-i hakla zapt ve hiraseti” yani Tuna Nehri'nde Osmanlı hâkimiyetini korumaktır. Bu yüzden mevcut gemileri donatarak Ruz-1 Hızır'dan 15-20 gün önce Tuna'nın buzları çözüldükten sonra ${ }^{19}$ Demirkapı'nın yukarısına doğru ilerlemesi ve düşmana karşı korunması gereken yerleri koruması gerekmekteydi ${ }^{20}$. Osmanlı ordusu batı yönünde seferde ise Tuna kaptanı da seraskerin yanında ve hizmetinde yerini almalıyd $1^{21}$. Onun emri altında görev yapan firkate, şayka, kalyete, tombaz ve üstüaçık kaptanları bulunmaktaydı. Tuna kaptanı, emri altındaki bu kaptanların yardımıyla Osmanlı ordusunun asker, erzak ve mühimmatlarını taşımalı ${ }^{22}$, Rahva, Belgrad, Varna, Niğbolu ve Silistre gibi önemli şehirleri takviye etmelidir ${ }^{23}$. Bu kadar önemli görevi aynı anda yerine getirmediği için ihmal ve gevşeklik suçlamasıyla görevinden azledilen kaptanlar bulunmaktaydı. Görevinde ihmal ya da gevşeklik göstermesinden dolay1 azledilen ya da görevden uzaklaştırılan kaptanların muhasebeleri yerlerine atanan yeni kaptan tarafından görülürdü. Yeni Tuna kaptanı eski Tuna kaptanının zimmetinde mürettebatın ücreti, mühimmat ve malzeme namına ne varsa devlet adına tahsil etmekle yükümlüydü. Ancak bu uygulamaya suçlu olduğu için görevinden alınan kaptanlar için daha sık başvurulmakta ve bu hususun üzerinde durulmaktadır ${ }^{24}$.

Tuna donanmasında görev yapan her geminin bir kaptanı ayrıca o kaptanın bağlı olduğu bir üst kaptan vardı. Örneğin firkate gemilerindeki kaptanlar üzerinde ayrı bir firkate kaptanlığı, şayka kaptanlarının bağlı olduğu şayka kaptanlığı ya da kalyete kaptanlarının bağlı olduğu bir kalyete kaptanlığı bulunmaktaydı. Bu kaptanlıkları üslenen kişiler gemicilik ve denizcilik işlerinde belli bir birikime sahip olan gemi kaptanlarıydı. Firkateler, şaykalar ya da üstüaçıklar başbuğu olarak isimlendirilen bu kaptanlar, emirleri altındaki gemilerin kalafatlanması dâhil her türlü donatımından Tuna kaptanına karşı sorumluydular. Bu iş için yapacakları masraflar merkezi idarece karşılanmakta ya da onların ocaklık gelirlerinden mahsup edilmekteydi. 1739/1740'de

\footnotetext{
16 Tuna donanması üzerine başbuğ tayin edilen Çadırcızade isimli kaptana 1202 (1787/1788) tarihinde gönderilen hükümde kendisinden gerek inşasına memur olduğu çete kayıklarını ve gerekse de iskelelerde bulunan şayka ve tekneleri eksiksiz biçimde donatıp hızlı bir şekilde Vidin'e hareket etmesi ve ardından Vidin seraskeri Hasan Paşa ile müzakere ederek Yukarı Fethülislam taraflarına ilerlemesi istenmiştir. (bk. BOA.C.BH.30.1421.2.1. )

${ }^{17}$ Belgrat kalesinin tahkim edilmesi için Tuna donanmasından 30 adet üstü açık gemisi tahsis edilmiş ve 27 Rebiyülahir 1159 (19 Mayıs 1746) da bu gemilerdeki kürekçi ve dümenci ücreti olarak 8,904 kuruş ödemek gerekmiştir. Bahsedilen üstü açıklar Belgrat'a kalesine taş, kireç ve kereste taşıma hizmetinde kullanılmışlardır. (bk. BOA.AE.SMHD.I.181.14120.1.1. )

18 Tuna kaptanı olarak 24 Cemeziyülahir 1153 (16 Eylül 1740) tarihinde tayin olunan Ahmet'in bu göreve atanmasının sebebi “...gerek donanma-yi hümayunun umurunda ve gerek sair fermanım olan hidemat-ı aliyemin eda ve temşiyet ve tekmilinde bezl-i iktidar ile mesai-i meşkurun zahir ve bedidar olduğu” yani liyakat ve beceri hususuna onun sahip olmasıydı. (bk. BOA.C.BH.224.19433.1.1.)

${ }^{19}$ BOA.A.DVNS.MHM.d.102.100. /Evasit Recep 1100 (Nisan/May1s 1690)

${ }^{20}$ BOA.A.DVNS.MHM.d.104.101. /Evahir Recep 1104 (Mart/Nisan 1693)

21 BOA.A.DVNS.MHM.d.104.101./Evail Recep 1100 (Nisan/May1s 1690), BOA.A.DVNS.MHM.d.100.9. /1101(1689/1690), BOA.A.DVNS.MHM.d.101, 24/ Evahir Recep 1103 (Mart/Nisan 1692).

${ }^{22}$ Denizlerde görev yapan gemiler derya gemileri ismiyle isimlendirilmişlerdir. Tuna donanmasının bir görevi de derya gemilerinden gelen asker, erzak ya da mühimmatı Tuna Nehri'nin Karadeniz'e kavuştuğu yerden teslim almaktır. (bk. BOA.A.DVNS.MHM.d.101.47/ Evahir Şevval 1102/Haziran-Temmuz 1691)

${ }^{23}$ BOA.A.DVNS.MHM.d.104.18. /Evahir Ramazan 1103 (Mayıs/Haziran 1692)

${ }^{24}$ BOA.A.DVNS.MHM.d.106.128. /Evasıt Muharrem 1107 (Ağustos/Eylül 1695)
} 
Tuna firkatelerinin başbuğu olan Ali Kaptan'dan Belgrat'ta bulunan 15 adet firkateyi Kili İskelesi'ne götürerek kalafatlatması ve ardından İstanbul'a getirmesi istenmiştir ${ }^{25}$. "Başbuğ " olarak isimleri belgelerde sıkça zikredilen bu kaptanlar, emirleri altındaki gemilerin yenilenmesi gerektiğinde bunu yazılı olarak devletten talep ederlerdi. Özellikle şaykaların yenilenmesinde bu usul ön plana çıkmaktaydı. Kanun gereği eskiyen ya da tamire ihtiyaç duyan gemilerin yenilenmesini onların kaptanları değil "başbuğ" olarak isimlendirilen bu kaptanlar talep etmekteydi. Ama talepte bulunmasalar bile 4-5 senede bir defa şayka türü bu gemiler tamir görmekte ve gemi kaptanlarına tamir masraflarını tahsil edecekleri bir hazine tezkiresi verilmekteydi ${ }^{26}$. Devlet bu kaptanları görevlerinde ihmal ya da gevşeklik göstermeleri halinde onları görevden almakta ya da ceza ile tehdit etmektedir ${ }^{27}$.

Tuna donanmasında savaş amacıyla tasarlanan gemilerin yanında askeri amaçla donatılmış olan tüccar gemileri de bulunmaktaydı. Buharlı gemiler çă̆ından önce mevcut olan sivil ve askeri gemiler arasındaki geçişkenlik 18. yüzyılda da devam etmekteydi. Devletler tüccar gemilerini satın alarak ya da kiralayarak onları silahlandırmakta ve askeri mürettebatla donatmaktadırlar. Olağanüstü durumlarda bu yola başvurulmakta olup Tuna donanmasında bu gemilerin donatılması ve bu gemi mürettebatının ücretlerinin ödenmesi Tuna kaptanının sorumluluğu altındayd ${ }^{28}$. Tuna kaptanının bu görevini ifa edebilmesi için kendisine tahsis edilmiş olan ocaklık gelirleri bulunmaktaydı. Bu ocaklık gelirinin miktarını gösteren ocaklık beratına sahip bu kaptanlar her padişah değişikliğinde bunu yeniletmek zorundaydılar ${ }^{29}$.

Ocaklık beratına, ocaklık usulüyle inşa edilmiş gemilerin kaptanları da sahipti. Onlar da her padişah değişikliğinde bunu yeniletmek zorundaydı. Bu kaptanlar ellerindeki ocaklık beratına dayanarak ilgili gelir kaleminden alacaklarını tahsil ederler ve bu hususa dair ocaklık gelirlerini aldıkları yerin eminlerinden ücreti aldıklarına ve gemiyi donatarak görev yerlerine hareket ettiklerine dair kadı huzurunda bir ilam alırlardı. Bu ilam hem görevi ihmal suçlamasında kendilerini savunmalarına imkân vermekte hem de devlete karşı görevlerini layıkıyla ifada kişisel bahane ileri sürmelerini önlemekteydi. Ayrıca kadı ilamını aldıktan sonra bu kaptanlar ocaklık vergi tahsildarlarından bir şey talep edemezlerdi. 1787/1788 yılında Silistre şaykası kaptanı Mehmet Kaptana Silistre İskelesi mukataasından ocaklık tahsis edilirken, Fethülislam şaykası kaptanı Abdullah Kaptan'a ise Niğbolu adet-i ağnam mukataasından ocaklık tahsis edilmiştii ${ }^{30}$.

Gemi kaptanlarının ölmesi ya da yaralanması halinde devlet bu duruma kayıtsız kalmayıp ölen kişinin ailesine sahip çıkmaktaydı. Örneğin tarihi belli olmasa da dil ve üslup olarak 18 . yüzyıla ait olduğu anlaşılan bir arzdan anlaşıldığı kadarıyla Tuna donanmasında görev yaparken düşmana karşı savaş sırasında bir sal yanmış (sal sefinesi) ve bu salın kaptanı olan Tayfur Kaptan hayatını kaybetmiştir. Onun oğlu ve eşi hayatlarını idame ettirmede zor durumda kalınca devlete başvurmuşlar ve kendilerine "mizan-ı harir"den 40 akçe aylık bağlanmıştır ${ }^{31}$.

Tuna kaptanı, yukarıdaki görevlerine ilave olarak Tuna Nehri kıyısında bulunan İbrail, Silistre, Niş, Belgrat, Vidin, Niğbolu ve Rusçuk gibi şehirlerin kalelerini tahkim etmekle de

\footnotetext{
${ }^{25}$ BOA.C.BH.130.6291.1.1. /10 Cemaziyülahır 1152 (14 Eylül 1739)

${ }^{26}$ Tuna Şaykaları Başbuğu Mehmet Kaptan, 1180 (1766/1767) tarihinde emri altında bulunan Vidin şaykası kaptanı Mustafa Kaptan'ın idare ettiği şaykanın eski ve kullanıma uygun olmadığını ifade ederek yenilenmesi maksadıyla devletten 230 kuruş talep etmiştir. Onun bu talebi kabul edilmiştir. (bk. BOA.C.BH.239.11073.1.1. )

${ }^{27}$ Firkateler Evahir Ramazan 1106'da (Nisan/Mayıs 1695) zamanında Tuna kaptanı Ali Paşa'ya katılmadıklarında devlet firkatelerin genel kaptanını uyarmış aynı durum tekerrür ederse özür ve cevaplarının kabul edilmeyip cezaya müstahak olacağını hatırlatmıştır. (bk. BOA.A.DVNS.MHM.d.106.42. )

${ }^{28}$ Tuna Kaptanı Seyyid Ahmet Paşa, 23 Zilkade 1205 (22 Temmuz 1791) tarihinde donanmadaki tüccar gemilerinde bulunan mürettebatın ulufe, bahşiş ve zahire bahaları için 12,792 kuruş ödeme yapmış ve bu ücret Hazine-i Âmire'den karşılanmıştır. (bk. BOA.C. BH.111.5400.1.1.)

${ }^{29}$ BOA.C.BH.254.11735.1.1. /22 Safer 1200 (25 Aralık 1785)

${ }^{30}$ BOA.C.BH.197.9240.2.1./10 Zilkade 1201 (24 Ağustos 1787)

${ }^{31}$ BOA.TS.MA.E.526.29.1.1.
} 
görevliydi. Buralara gönderilen askerleri gerekli olan mahallere yerleştirmek ya da leventlerden takımlar oluşturarak müstahkem mevkilerin nehir tarafından korunması için bunları seferber etmek onun görevine dâhildi. Nisan/Mayıs 1695 tarihinde Tuna Kaptanı Ali Paşa'ya Edirne'den gönderilen 400 kadar levendi Niş taraflarındaki mahallere yerleştirmesi emredilmiştir ${ }^{32}$. Savaş zamanında bunun için İstanbul'dan gelen mübaşirler ona yardımcı olmakla yükümlüydü. $\mathrm{O}$, bu mübaşirler yardımıyla her biri 5-6 kişiden oluşan dalkılıç takımları oluşturur, bunlara "ağa" ve "alemdar" tayin eder ve bunların ücretini İstanbul'dan gelen mübaşirlerden teslim aldı ̆̆ ücretten öderdi. Serdengeçtilerden oluşan dalkılıç takımlarının görevi, nehir yönünden Osmanlı kalelerini korumaktır. Bu takımlara ödenen ücrete, barut ve kurşun akçesi adıyla ödenen ücret de dâhildi. Daha sonra ise dalkılıç olarak yazılan kişilerin isimlerini muhtevi defter padişaha arz edilmek üzere İstanbul'a yollanırd1 ${ }^{33}$. Tuna donanmasındaki mürettebatın ücretlerinin ödenmesi de Tuna kaptanının sorumluluğundaydı. Esasen mürettebata ücret mart-kasım ve kasım-mart şeklinde 6 aylık periyodlar halinde ve senede iki defa ödenmekteydi. Ücrete yemek bahası ile aylık dâhil olup bu ücret peşin ve nakit olarak ödenmekteydi ${ }^{34}$.

Tuna Nehri'nde görev yapan şayka, firkate, üstüaçık, tombaz ya da kalyete gibi gemilerin inşa edildikleri bölgelerden donatılması genel usul ise de bazen top, yelken bezi, urgan, halat ve üstüpü gibi malzemelerin İstanbul'daki Tersane-i Âmire'den gönderildiği görülmekteydi. Örneğin 2 Nisan 1791 tarihinde Tuna'da inşa olunan şalopa, duba ve sal gemileri için Tersane-i Âmire'den Varna'ya gönderilen malzemeler şunlard $1^{35}$;

1. Katran $(52 \mathrm{Kantar} / 2933,216 \mathrm{~kg})$

2. Zift (323 Kantar/18219,784 kg)

3. $\quad$ Gomina $^{36}(237 \mathrm{Kantar} / 13368,696 \mathrm{~kg})$

4. Demir lenger $(102 \mathrm{Kantar} / 5753,616 \mathrm{~kg})$

5. $\quad$ Üstüpü ${ }^{37}(66 \mathrm{Kantar} / 3722.928 \mathrm{~kg})$

6. Reçine (65 Kantar $/ 3636,52 \mathrm{~kg})$

7. Kirpas Boğaz (1025 top)

8. Kirpas yeşil sancak. (252 vukiyye $/ 323,064 \mathrm{~kg}$ )

9. Fitil (294 vukiyye $/ 376,908 \mathrm{~kg})$

10. Çeşitli makaralar (400 zira'/303,496 m)

Tersane-i Âmire devletin hem en büyük tersanesi hem de donanmanın ana ikmal üssüydü. Kanun gereği ocaklık yoluyla imparatorluğun pek çok noktasından toplanan kereste, tel, üstüpü, sicim zift, katran ve yelken bezi gibi gemi malzemeleri burada bulunan Mahzen-i Cub ve Mahzen-i Sürb'te depolanmaktaydı. Dolayısıyla gemi inşa ve donatım malzemelerine Tersane-i Âmire diğer tersanelere göre daha fazla sahiptir. Buradan Tuna donanması için malzeme gönderilmesini Tuna kaptanı isteyebileceği gibi serasker sıfatıyla sadrazam ${ }^{38}$ ve donanma komutanı sıfatıyla kaptan-1 derya da isteyebilirdi. Ancak bu istekler karşısında son söz merkezi otoritenin temsilcisi olan padişahındır. Merkeziyetçi idari yapının bir sonucu olarak padişah teorik olarak dilerse bu isteği kabul edebilir dilemezse reddedebilirdi. Talep kabul edilirse malzemelerin listesini içeren defter

\footnotetext{
${ }^{32}$ BOA.A.DVNS.MHM.d.106.35

${ }^{33}$ Evahir Cemeziyülahir 1205 (Şubat/Mart 1791) tarihinde İbrail kalesinin nehirden muhafazası için tutulan dalkılıç takımlarının ağalarına bu iş için İstanbul'dan gönderilen 10, 000 kuruştan Tuna kaptanı tarafından 20, alemdarlarına 10 ve neferlerine 5 kuruş ödeme yapılmıştır. Daha sonra ise bu kişiler gemi ve kayıklara bindirilerek İbrail'deki çete kayıklarının başbuğu olan kaptanın emrine verilmişlerdir. (bk. BOA.C.BH.186.8750.3.1.)

${ }^{34}$ BOA.C.BH.126.6111.1.1. /2 Muharrem 1240 (27 Ağustos 1824)

${ }^{35}$ BOA.C.AS.1008.44134.1.1. /28 Recep 1205. (2 Nisan 1791)

${ }^{36}$ Gomina, gemi lengerlerinin bağlanıp atıldığı zincirlere denmektedir. (bk. Gürçay, age., s. 185. )

${ }^{37}$ Üstüpü, katranlı halat eskilerinin didiklenmiş halidir. Gemilerin kalafatlanmasında kullanılmaktadır. (bk. Lütfi Gürçay, Gemici Dili, Deniz Basımevi, İstanbul, 1962, s. 397. )

${ }^{38}$ Dönemin sadrazamı 7 Şevval 1205 te (9 Haziran 1791) Varna kazasının korunması için bir adet balyemez topu ile Tuna donanması için Tersane-i Âmire'den gönderilmek üzere top, yelken, demir, halat ve sair malzemenin bir an önce Varna'ya gönderilmesini talep etmiştir. (bk. BOA.C.AS.996.43544.1.1. )
} 
baş muhasebeye gönderilir ve baş muhasebeden talep edilen malzemelerin fiyatları çıkarılarak satın alma işlemi gerçekleştirilirdi. Tüccarlara ve devlete malzeme satan kişilere malzemeyi teslim ettikleri makam tarafından devletten alacaklı olduklarına dair bir tezkire düzenlenir onlar da bu tezkireye dayanarak ocaklık gelirinin kaynağı olan mukataadan alacaklarını tahsil ederlerdi.

Tersane-i Âmire'den teslim alınan donatım malzemeleri, tutulan gemiler vasitasıyla Varna ve Silistre gibi önemli kazalara gönderilirdi. Gönderilen malzemeler her zaman deniz yoluyla değil bazen de karadan arabalar kiralanmak suretiyle Tuna donanmasına ulaştırılmaktaydı. Mekkari teşkilatı bu işin ifasında rol üslenmişti ${ }^{39}$. Bu iş için özel mübaşirler tutulur ve onun tutmuş olduğu arabaların ücretleri baş muhasebe vasıtasıyla devletçe karşılanırd ${ }^{40}$. Bu nakliye, deniz yoluyla gerçekleșecekse gemilerinin başına birer reis atanır ve ücreti İstanbul gümrüğü mukataasından ya da Hazine-i Âmire'den ödenirdi ${ }^{41}$. Tersane-i Âmire'nin yanında Cebehane-i Âmire ve Tophane-i Âmire gibi kurumlar da Tuna donanmasının donatımında görevliydi. 1790/1791 yılında Cebehane-i Âmire'de bulunan kalyon demirlerinin Tuna'da görev yapan şalopalara lazım olduğu anlaşılınca bunlar önce Silistre'ye daha sonra ise Rusçuk'a gönderilmiştir ${ }^{42}$.

Ad1 geçen kurumlarda bulunamayan malzemeler ise İstanbul'da bulunan tüccarlardan piyasa rayicine göre satın alınmaktaydı. Örneğin 80 adet sandal ve 20 adet şalopaya gerekli olan 1258 top mayistra cinsi yelken bezi 11,164 kuruş bedel ile İstanbul'da bulunan tüccardan satın alınmıştı ${ }^{43}$. İstanbul'dan sadece donatım malzemeleri değil marangoz, burgucu ve kalafatçı amelesi gibi uzman işgücü de gönderilmekteydi. Bu işgücü deniz yolunun yanı sıra kara yolu kullanılarak İstanbul-Edirne-Varna yoluyla Silistre'ye ulaştırılmaktayd $1^{44}$. 1791/1792 y1lında 2 burgucu 30 kalafatçı ve 1 mimar İstanbul'dan Varna'ya gönderilmişti ${ }^{45}$. İnşa edilen gemiler için gerekli olan kürekçi ve cenkçiler ise Kili, Akkirman ve İbrail gibi önemli kazalardaki askerler ile bu kazaların ahalilerinden karşılanmaktaydı. Ancak sürekli olarak aynı kazalardan kürekçi ve cenkçi temin edilmesi bu kazalardaki ahalinin şikâyetine sebep olmuştur ${ }^{46}$.

Tuna donanmasının inşasında kullanılan kerestelerin Eflak Eyaleti’nden temini yaygın bir uygulamaydı. Ancak 18. yüzylla gelindiğinde burada bulunan ormanlar ihtiyaca cevap veremez hale gelince Silistre karşısındaki kazalardan kereste temin edilmeye çalışılmış ancak bu kazalarda orman olmayınca Yergöğü'nden 12 saat uzakta bulunan ve Büyük Eflak'ta yer alan Vlaşka Kazası'ndaki ormanlardan bunların temin edilmesi cihetine gidilmiştir. Buna göre Vlaşka ormanlarından kesilen keresteler Yergöğü'ne nakledilmiş daha sonra ise Silistre'den gelen üstüaçık gemilerine yüklenerek Silistre'ye taşınmıştır. Eflak'tan bunun dışında marangoz, bıçakçı ve hararcı gibi iş gücü de temin edilmektedir ${ }^{47}$. Ayrıca gemilerdeki savaşçı unsurlar için de Eflak, kendisine

\footnotetext{
39 Tuna kaptanı Ahmet Paşa'nın talebi üzerine 42 kantar 2 vukiyye çivinin mekkariden temin edilecek arabalar vasıtasıyla ona gönderilmesine 12 Şaban 1205 (16 Nisan 1791) tarihinde karar verilmiştir. (bk. BOA.C.BH.275.12678.1.1. )

${ }^{40}$ BOA.AE.SSLM.III.116.7068.1.1./5 Şaban 1205 (9 Nisan 1791)

${ }^{41}$ İstanbul gümrük emini tarafindan yazılan 29 Rebiyülevvel 1206 (26 Kasım 1791) tarihli bir arzda Tuna donanması için talep edilmiş olan 2 kaptan, 2 reis, 1 mimar, 2 burgucu 30 kalafatçı, 3 adet bakır kazan, 3 adet bakır zift kevgiri ve kepçesinin reisler kethüdası marifetiyle tutulan gemiler için 150 kuruş yolluk ücretinin Hazine-i Âmire'den ödenmesi talep edilmiştir. (bk. BOA.C.BH.174.8205.1.1.)

${ }^{42}$ BOA.C.BH.41.1933.1.1.

${ }^{43}$ BOA.C.BH.15.749.1.

${ }^{44}$ Tuna donanmasında istihdam olunmak üzere 19 Rebiyülahir 1206 (16 Kasım 1791) tarihinde İstanbul'dan kaptanlar, Arap reisler, marangozlar, burgucular ve kalafat ameleleri Silistre’ye gönderilmiştir. (bk. BOA.C.BH.6.285.1.1. )

${ }^{45}$ BOA.C.BH.174.8205.1.1. /29 Rebiyülevvel 1206 (26 Kasım 1791)

46 Kili kalesinin askerleri padişaha arzuhal göndererek 1100(1688/1689), 1101(1689/1690) ve 1102(1690/1691) senelerinde Tuna donanması gemileri için üç senede 170 asker verdiklerini artık asker göndermeye takat ve iktidarlarının kalmadığından şikâyette bulunmuşlardı. Bunun üzerine Akkirman kalesinden 5o askerin cenkçi olarak gönderilmesine karar verilmiştir. (bk. BOA.A.DVNS.MHM.d.104.68. )

${ }^{47}$ Eflak voyvodası Mihal'e yazılan bir hükümde kendisinden 50 kadar marangozu bir tanesi bile firar etmeyecek şekilde kefalete bağlayarak Silistre'ye göndermesi istenmiştir. Tuna kaptanı Ahmet Paşa, donanmasının tamiri ve bir tane firkateyn gemisinin inşası için lüzumlu olan kereste, sütun, demir, neccar bıçakçı ve hararcı gibi işçilerin Eflak’tan
} 
bu dönemde s1kça başvurulan bir eyalettir. Örneğin 1695/1696 yılında Tuna kaptanı Ali Paşa azledildiği zaman bunun sebeplerinden birisi “...Eflak'tan işe güce ve cenge ve harbe yaramaz adamlar yazup..." hususuydu ${ }^{48}$. Bu bilgi Eflak'ın sadece uzman iş gücü için değil aynı zamanda savaşçı insan gücü olarak da değerlendirildiğini göstermektedir.

18. yüzyılın sonlarına doğru önemli Tuna şehirleri üzerindeki devlet hâkimiyetinin zayıflaması ya da yitirilmesi sonucunda Karadeniz kıyısında bulunan Silistre tersanesi, Tuna donanması için önem kazanan bir tersane olmuştur. Burası Tuna gemilerinin hem inşa edildiği hem de kışlamak için kullandığg bir üs konumundadır.

Gerek Silistre'de olsun ve gerekse Rusçuk ve gerekse diğer tersanelerde olsun kavak kerestesi $^{49}$ ve tapa ${ }^{50}$ tahtaları Tuna donanmasında yaygın olarak kullanılmaktaydı. Bu keresteleri taşıma işi 18. yüzyılda genelde ayanlar tarafindan yapılmaktaydı. Rusçuk ayanları bu işte ön plana çıkmışlardı ${ }^{51}$. Serez Kazası'ndaki ayanlar ise devletin talebi üzerine şayka inşa etmekteydi ${ }^{52}$. Devletin zor durumlarda daha sık başvurmaya başladığ 1 yerel ayanlardan böyle taleplerde bulunmasının sebebi, bu kişilerin bulundukları yerde hem sözü dinlenen hatırlı kimseler olması hem de kendilerinden istenen işi yapacak ekonomik güce sahip bulunmalardır. Devletle kurdukları kişisel ve ticari ilişkiler bu ekonomik gücün hem sebebi hem de sonucudur. Bu ilişkiler onları iktisadi olarak güçlendirmiş, güçlendikçe ise devletle olan ilişkileri derinleşip gelişmiştir. $\mathrm{Bu}$ ayanlar, kereste nakliyatında kullanılan sivil gemileri kiralamakta, gemi kaptanlarına mühürlü tezkire vermekte onlar da nakliye işi bittikten sonra alacaklarını devletten tahsil etmektedir ${ }^{53} . \mathrm{Bu}$ aracılık hizmeti sayesinde Rusçuk ayanları bölgelerinde hem ekonomik güçlerini arttırmışlar hem de devlet nezdinde itibarlarını güçlendirmişlerdir. Varna ayanları ise bu şehirde bulunan zahire ambarlarının tamiri işini üslenmişlerdir. 2 Nisan 1791'de Varna'da bulunan 12 adet ambarın tamir işi Varna Ayanı Seyyid Mustafa Ağa tarafından üstlenilmişti. Bu 12 ambardan 2'sinde Bergos'tan gelen arpa ve peksimet depolanmış olup bunlar gönderildikten sonra ise bunların tamir işi de aynı kişi tarafindan gerçekleştirilmiş ve 12 ambarın tamir masrafları kadı huzurunda defter haline getirilerek İstanbul'a gönderilmiştir ${ }^{54}$.

Gemilerin kalafatlanmasında ${ }^{55}$ kullanılan katran ve zift, Tuna Nehri'ne komşu olan iskelelerden karşılanmaktaydı. Kalafat konusunda Silistre, Varna ve Kili kazaları bu yüzyılda temayüz etmiştir. Kalafat için ihtiyaç duyulan zift, katran ve üstüpü buralardan karşılanmaktaydı. Örneğin 29 Aralık 1791 tarihinde Varna'dan her kantarı 7 kuruştan 40 kantar zift 280 kuruşa satın alınmış ve Silistre'ye gönderilmişti. Bunun ücreti ise ordu hazinesinden karşılanmışt1 ${ }^{56}$. Katran ve zift şayet yeterli miktarda Tuna şehirlerinde bulunamaz ise bu takdirde Tersane-i Âmire'den gönderilerek karşılanmaktayd1 ${ }^{57}$. Demir ise Rusçuk ve Ziştovi'deki tüccarlardan satın alınmaktaydı.

toplanmasına ihtiyaç duyulduğunu bildirmiştir. Onun bu talebi her ne kadar Eflak'tan tam olarak karşılamasa da Eflak'ın bu konuda üslendiği rolü göstermesi açısından dikkat çekicidir. (bk. BOA.C.BH.164.7750.1.1.)

${ }^{48}$ BOA.A.DVNS.MHM.d.106.128. /Evasit Muharrem 1107 (Ağustos/Eylül 1695 )

${ }^{49}$ Kavak keresteleri hafif olmakla gemilerin hız yeteneklerini artırmakla beraber top atışları ya da dışardan darbelere karşı zayıftır. Meşe kerestesi ise Avrupa donamalarında daha çok tercih edilmektedir. Çünkü hem dayanıklı hem de top güllesi isabet ettiğinde etrafa fazla parça saçıp mürettebata zarar vermemektedir.

${ }^{50}$ Tapa, humbaraların bir yerde tutulmasında veya içindeki barutu tutuşturmakta ağızlarına konulan tertibattır. Güverte ve borda kaplamalarında bulunan çivi ve cıvata başlarını kapamak için vurulan ve mancana deliklerine koşulan ağaç kavelelere de tapa denmektedir. (bk. Lütfi Gürçay, age., s. 363)

${ }^{51}$ BOA.C.BH.73.3473.1.1. /6 Cemaziyülevvel 1206 (1 Ocak 1792)

52 BOA.A.DVNS.MHM.d.98.36. /Evail Rebiyülevvel 1100 (Aralı/Ocak 1688/1689)

${ }^{53}$ BOA.C.BH.73.3473.2.1. / 6 Cemaziyülevvel 1206 (1 Ocak 1792)

${ }^{54}$ BOA.C.AS.1008.44134.3.1. /28 Recep 1205 (2 Nisan 1791)

${ }^{55}$ Kalafat, gemilerdeki kaplama ve güverte döşeme tahtalarının arasına su girmemesi için üstüpü sıkıştırdıktan sonra üzerini zift ve katranla kapatmaktır. (bk. Lütfi Gürçay, age. , s. 221)

${ }^{56}$ BOA.AE.SSLM.III.136.8220.1.1./3 Cemaziyülevvel 1206 (29 Aralık 1791)

${ }^{57}$ Tuna donanmasındaki 11 gemi için Tersane-i Âmire'den 25 Recep 1205 (30 Mart 1791) tarihinde 675 kantar zift, 35 fıçı katran, 100 kantar reçine gönderilmiştir. bk. BOA.C.BH.222.10341.1.1. ; İstanbul'dan Silistre'ye 19 Rebiyülahir 1206 (16 Aralık 1791) tarihinde 546 kantar zift ve 88 kantar katran gönderilmiştir. bk. BOA.C.BH.6.285.1.1. ; 
Bununla birlikte İstanbul'da bulunan Cebehane-i Âmire'den demir talep edilmiş olduğuna dair kayıtlar da vardır. Örneğin 9 Nisan 1791'de Rusçuk'ta inşa edilen şalopa ve duba gemileri için 100 kantar demir gerektiğinde Cebehane-i Âmire'ye başvurulmuş ve gerekli olan demir gönderilmiştir ${ }^{58}$. Gemilerde kullanılan toplar ise Tophane-i Âmire'de dökülmektedir ${ }^{59}$.

İnce donanma gemilerinde bulunan dümenciler Tuna donanması için önemli bir işgücünü oluşturmaktaydı. Tuna Nehri üzerindeki girdaplar dümencilerin önem kazanmasına neden olmuştur. Tuna donanması gemilerinde çalışan dümencilerin önemli bir kısmı Eflak'tan karşılanmaktaydı. Eflak voyvodaları, bu kimseleri Tuna kaptanına teslim etmekle yükümlüydü. Dümencilerden kaçmamaları için kefilleri alınır ve isimleri kefilleriyle birlikte defter haline getirilerek İstanbul'a gönderilirdi ${ }^{60}$. Gemi inşa ve donatımında görev alan marangozlar ve demirciler Niğbolu, Ziştovi, Rusçuk, Silistre ve Yergöğü gibi kazalardan temin edilmekteydi. 1787/1788 yılında Tuna kaptanı Çadırcızade Mehmet Ağa'ya 15 adet çete kayığı inşa etmesi emredildiğinde ihtiyaç duyulan 120 marangoz ile 17 demirci adı geçen kazalardan temin edilmiştir ${ }^{61}$.

Tuna donanması Ruz-1 Hızır'dan Ruz-1 Kasım'a kadar olan 6 aylık bir dönem boyunca faaliyet göstermekteydi. Kasım ayında ise tıpkı Osmanlı donanmasının Tersane-i Âmire'ye çekilmesi gibi o da kendi kışlağına çekilmekteydi. Bu kışlaklar Belgrat, Semendire, Varna, Silistre, Rusçuk gibi Tuna sahilindeki kazalardaydı. Belgrad'ın Orta Avrupa'ya açılan stratejik konumu nedeniyle bu konuda ayrı bir önemi vardı. 1698/1699 tarihli bir belgede geçen “...her sene Belgrat'ta kışlağa vaz' olunagelmeğin" ifadesi onun uzun zamandır Tuna donanması için bir kışlak işlevi gördüğünü göstermektedir ${ }^{62}$. Kasım ayından sonra gerçekleşen bu kışlağa çekilme faaliyeti sırasında bütün gemilerin tek bir kışlağa çekilmesi yerine şaykaların, kalyetelerin, firketelerin ya da üstüaçıkların ayrı ayrı kışlaklara çekilmesi şeklinde bir uygulama bulunmaktadır. Buna göre bazen kalyete ve firkateler Belgrat'a çekilirken şaykalar Rusçuk'ta kışlağa çekilmektedir. Bu uygulamanın güvenlik endişesi ve kışlamada kolaylık gibi pratik nedenlerden kaynaklandığı düşülmektedir. Donanma bu kışlakların dışında padişahtan gelecek emir üzerine İstanbul'a gelip Tersane-i Âmire'de de kışlayabilirdi ${ }^{63}$. Bu konuda söz sahibi olan donanmanın da sahibi olan padişahtır. Tuna kaptanı ince donanmanın kışlama faaliyeti bittikten sonra İstanbul'a dönerdi. Padişahın fermanı olmadıkça onun donanmayı kışlatması ya da donanma kaptanlığından ayrılarak İstanbul'a dönmesi mümkün değildir ${ }^{64}$. Bu kural denizlerde faaliyet gösteren Donanma-yi Hümayunu yöneten kaptan paşalar için de geçerlidir. Donanma kışlağına çekildikten sonra içindeki malzemeler ilgili kazanın kalesinde, gelecek sefer dönemine kadar depolanırdı. Bunun sebebi mühimmat ve malzemelerin hava koşulları nedeniyle bozulmasına engel olmak ve hırsızlık, yağma ya da yangın gibi durumlara karşı daha iyi muhafaza edilmesini sağlamaktır. Gemilerin üzeri ise kar ve yağmurdan korunmak için bir bezle kapatılır, hırsızlık, yağma ya da sabotaj gibi unsurlara karş1 bekçiler tayin edilirdii ${ }^{65}$. Rusçuk'ta kışlamak için karaya çekilen gemileri korumak için

Yergöğü'nde 1202 (1787/1788) yılında inşa olunacak 15 adet çete kayıkları için toplar İstanbul'dan gönderilmiştir. bk. BOA.C.BH.215.10043.1.1.

${ }^{58}$ BOA.C.BH.275.12678.1.1.

${ }^{59}$ BOA.A.DVNS.MHM.d.103. 27/Evasıt Cemaziyülahır 1105 ( Ocak/Şubat 1694)

${ }^{60}$ BOA.A.DVNS.MHM.d.99.79. /Evasit Recep 1101(Nisan/Mayıs 1690)

${ }^{61}$ BOA. C.BH.215.10043.1.1./10 Şaban 1202. (16 Mayıs 1788)

${ }^{62}$ Tuna donanmasına ait 10 adet kalyete ile 5 adet büyük firkate Belgrat'a 1110 (1698/1699) yılında çekilmiş ve içindeki 151 top Belgrat tophanesine teslim olunmuştur. (bk. BOA.C.BH.181.8494.4.2. )

${ }^{63}$ Tuna firkateler başbuğu olan Ali Kaptan'a 10 Cemaziyülahır 1152 (14 Eylül 1739) tarihinde Tuna'da gerekli olmadığı düşünülen 15 firkate, 6 aktarma ve 5 kancabaş ile kasım ayı gelmeden önce İstanbul'a gelmesi emredilmiştir. (bk. BOA.C.BH.130.6291.1.1.)

${ }^{64}$ BOA.İE.BH.7.574.1.1. $/ 5$ Rebiyülevvel 1103 (26 Kasım 1691)

${ }^{65}$ Rusçuk kadısı, dizdarı ve kale ağaları ile iş erleri ve vilayet ayanları Rusçuk'ta karaya çekilen gemilerin bulunduğu mahallin çevresi açık olduğu için gemilerin yağmur ve kar altında zarar göreceği kaçınılmaz olduğu gerekçesiyle uyarılmışlardır. Onlardan gemilerin bulunduğu mahallin etrafını duvarla çevirmeleri ve bu mahallin üstünün örtülmesi istenmiştir. (bk. BOA.C.BH.181.8494.4.2. ) 
Yergöğü kadısı ve dizdarı görevlendirilmiş̧ir. 23 Şubat 1699 tarihinde bu iş için Yergöğü’nden bir bölükbaşı ve 20 asker sevk edilmiştir ${ }^{66}$. Aynı yıl Belgrat'ta kışlayan 10 kalyetenin her birine 7 bekçiden toplam 70 bekçi, 5 firkatenin her birine 3 bekçiden toplam 15 bekçi kasım ayından mart ayına kadar 6 aylık bir süre için tayin olunmuşlardır. Her bir bekçi içinse 10 kuruş ücret verilmiştir. $\mathrm{Bu}$ kişilerin peksimetlerinin ise Belgrat ambarından verilmesi kararlaştırılmıştır ${ }^{67}$. 19. yüzyılın başlarında ise muhafaza amacıyla kayıkhaneler yapılmaya başlanmıştır ${ }^{68}$.

Malzemeler teslim edilirken bu işlem kadı ve şahitler huzurunda gerçekleşir, Tuna kaptanı teslim etmiş olduğu malzemeleri içeren listeyi şahitler huzurunda bunları muhafaza edecek görevliye teslim eder, o da bu malzemeleri teslim aldığını beyan ederdi. Kadı tarafından bu hususa dair Tuna kaptanına bir ilam verilir o da bu durumu padişaha arz ederdi. Açıklık ve şeffaflığ temel alan böyle bir merasimin sebebi ise Tuna kaptanını ve muhatabını zimmet ve hırsızlık suçlamalarından peşinen kurtarmaktır. Tuna Kaptanı Mehmet Paşa, 1702/1703 yılında Rusçuk kalesi dizdarı Ahmet Ağaya böyle bir merasimin sonunda donanmanın koğuş, tunç ve saçma topları ile onun malzemeleri olan barut, kurşun ve demir saçmaları teslim etmişti. Ahmet Ağa, kadı ve tanıkları huzurunda bunları teslim aldığını ve kaleye koyduğunu beyan etmiştir ${ }^{69}$.

Tuna kaptanı Ahmet Paşa'nın Kasım/Aralık 1791 tarihinde Semendire Kalesi Dizdarı elHac Osman Ağa'ya teslim ettiği malzemeler şu şekildeydi ${ }^{70}$;

1. Mayistra yelkeni (22 Adet)

2. Gabya yelkeni (19 Adet)

3. Balkon yelkeni (9 adet)

4. Babafingo yelkeni (3 Adet)

5. Mancana yelkeni (2 adet)

6. Şayka yelkeni( 6 adet)

7. Mayistra aletleri (8 parça)

8. Gabya aletleri (2 adet)

9. Gomina aletleri (2 adet)

10. Köhne aletler (14 adet)

11. Kazan (3 adet)

12. Fitil ağacı ( 9 adet)

13. Misır fitili (48 adet)

14. Köhne kepçe (29 adet)

15. Küçük nehir lengeri (3 adet)

16. Şayka küreği (30 adet)

17. Kapak makara (58 adet)

18. Mum (2 adet)

19. Siyah barut (52 kantar)

20. İki yüzlü keser (1 adet)

21. Demir kürek (3 adet)

22. Varil (52 adet)

23. Demir maymuncuk (2 adet)

24. Kargabaşı (4 adet)

25. Çarmık (6 adet)

26. Meşin kese (22 adet)

27. Hartuç çantası (2 adet)

\footnotetext{
${ }^{66}$ BOA.C.BH.181.8494.4.2.

${ }^{67}$ BOA.İE.BH.10.900.1.1. /29 Rebiyülahir 1110 (4 Kasım 1698)

${ }^{68}$ BOA.C.BH.108.5233.2.1. /4 Cemaziyülevvel 1230 (14 Nisan 1815)

${ }^{69}$ BOA.C.BH.181.8494.2.1./24 Cemaziyülevvel 1114 (16 Ekim 1702)

${ }^{70}$ BOA.D.BKL.d.32663.1.
} 


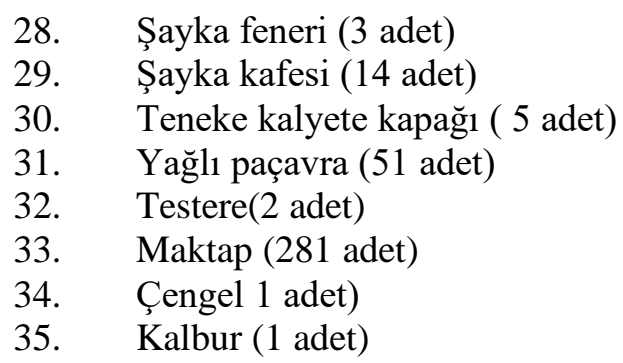

Semendire kalesindeki topçu başı vekili İbrahim ağaya teslim edilen toplar ise şunlard1 ${ }^{71}$;

1. Şahi top ( 1 adet 5 karış uzunluğunda)

2. $\quad$ Şahi top ( 1 adet 3 karış uzunluğunda)

3. Demir top (3 adet 14 karış uzunluğunda)

4. Demir top ((3 adet 26 karış uzunluğunda)

5. Demir top (1 adet 12 karış uzunluğunda)

6. Şahi top ((1 adet 14 karış uzunluğunda)

7. Şahi top ( 1 adet 7 karış uzunluğunda)

Silistre Kazası'nda ve Tuna sahilinde bulunan Tersane-i Mamure olarak isimlendirilen yerde, aynı merasimin sonunda depolanmış olan donanma malzemeleri ise şunlard1 ${ }^{72}$;

1. Mayistra ve gabya çarmıkları (144 adet-Köhne)

2. Mizana çarmıkı aletleri (7 adet )

3. Gomina aletleri(6 adet köhne )

4. Tunc ziban (1 adet )

5. Kanca (2 adet )

6. Yüklü hartuç (200 adet )

7. Ağaç tokmak (15 adet)

8. Gabya yelkeni (6 adet)

9. Mizana yelkeni (2 adet )

10. Tunçtan mamul dilli makara (4 adet)

11. Demir top (6 adet)

12. Mükemmel kundaklı top (4 adet, 2 karış uzunluğunda)

13. Mükemmel Nemçekari Kahire Kundağ 1 (1 adet)

14. Mükemmel Nemçekari araba üzerine top ( 7 adet 29 karıș)

15. Mükemmel kundağı üzerine top(2 adet)

16. Demir kollu tombaz (4 adet)

17. Kapaklı cephane arabasi(2 adet)

18. Matkap( 200 adet $)$

19. Şali hartuç (100 adet)

20. Yüklü kağıt hartuç(1 adet)

Kalelere teslim edilen malzemeler gemi malzemeleri ve savaş malzemeleri olmak üzere iki gruptur. Gemi malzemeleri yelken, gomina, kanca, çarmık, mum ve kürek gibi malzemeler iken savaş malzemeleri top, hartuç, yağlı paçavra, siyah barut ve top arabasıdır. Yelkenler mayistra, mancana ve gabya gibi isimler taşımakta olup toplar ise şahi ve demir toplardır. Yelkenlerin üretimi uzman ve teknik iş gücü gerektirdiği için bunların ise Tersane-i Âmire'de yoğunlaşmış olması nedeniyle yelken bezleri genelde İstanbul'dan gönderilmiştir. Toplar ise genelde Tophane-i Âmire'de üretilmiş olan toplardır. Tuna donanmasında kullanılan şahi türü toplar 15. ve 16. yüzyılda tasarlanmış dökme ve kalıp usulüyle üretilmiş olan toplardır. Bu toplar kütle olarak ağır

${ }^{71}$ BOA.D.BKL.d.32663.1.

${ }^{72}$ BOA.D.BKL.d.32663.1.

www.turkishstudies.net/turkishstudies 
olup seri atış yapma imkânı zayıf toplardır. 18. yüzyılda ise Avrupa'da bunun tersine demiri kalıbı delme usulüyle toplar imal edilmekte olup bu toplar hem daha hafif hem de daha hızlı atış yapma imkânına sahiptir. Ağızdan değil kundaktan ateşlenmektedir. Osmanlı devleti 1770'lerden itibaren Baron De Tott'un gayretleriyle bu yönde çalışmalara yoğunlaşmış ve III. Selim döneminde(17891808) yılında Hasköy'de açılan bir fabrikayla epey mesafe almıştır. (Grant, 2011:69).

\section{Donatım Masrafları}

Gemilerin inşa ve donatımı büyük masraflar gerektirmekteydi. Kullanılan malzemeler hammadde olmaktan çok işlenmiş maddeler olup çalı̧̧anlar ise nitelikli işgücüne sahip insanlardır. $\mathrm{Bu}$ da onlara ödenecek ücreti yükseltmekteydi. Gemi tasarımı yüksek mühendislik, matematik ve coğrafya bilgisi gerektirdiğinden denizcilik vizyonuna sahip bütün devletlerde gemi inşa ve donatımı yüksek bütçeler ve masraflar gerektiren bir alan olmuştur. Osmanlı Devleti için de geçerli olan bu husus onun bu alanda Hazine-i Âmire, İstanbul gümrüğü mukataası, Rusçuk, Niğbolu ve Silistre mukataaları gelirleri gibi birçok gelir kaynağını seferber etmesini gerektirmiştir. Bazen müsadere gelirlerinin bile bu iş için seferber edilmesi gerekmiştir. Harcamaların yüksek olması dolayısıyla tek bir gelir kaynağına bu harcamaları havale etmek yerine mevcut gelir kaynăğnı kurutmamak adına birden fazla gelir kaynağı arasında bu harcamalar bölüştürülmüştür. Yapılan ödemeler ise bazen ocaklık usulüyle bazen de doğrudan hazine tarafından satın almalar şeklinde gerçekleştirilmiştir.

\subsection{Hazine-i Âmire:}

Hazine-i Âmire, para işlerini görmek için kurulmuş kurumlardan birisidir. Hazine-i Âmire, başlangıçta Baruthane-i Âmire'nin veznesi mahiyetinde kurulmuş olup ismi devlet kasası anlamında kullanılmıştır. Bu hazinenin İç Hazine ve Enderun Hazinesi gibi bölümleri vardır. (Pakalın, 1983: 786). Tuna Nehri’ndeki gemilerin tamir ve donatımında buradan yararlanıldığ anlaşılmaktadır. Örneğin 8 Şubat 1789 tarihinde şayka kaptanlarından Mehmet Kaptan, padişaha bir arzuhal sunarak kaptanı olduğu şaykanın tamir masrafı olarak 120 kuruşun Hazine-i Âmire'den ödenmesini talep etmiştir ${ }^{73}$.

\subsection{Rusçuk Cizyesi Malları}

Bazı kazaların cizye gelirleri Tuna donanmasının donatımı için ocaklık olarak tahsis edilmiştir. İdari teşkilatın dışında devletin bir kısım giderlerinin karşılanması için bazı gelir kaynaklarının tahsisine ocaklık denilmektedir. Ocaklık, Tersane-i Âmire masraflarına karşılık olarak tahsis olunan aşar veya örfi hasılat yerine kullanılan bir tabirdir. Örfi hasılat teriminden anlaşılacağ 1 üzere cizye, mizan harir ve gümrük vergileri de ocaklık tahsis olunmaktadır. (Pakalın, 1983: 713). Ocaklık olarak tayin edilen miktar, ihtiyacı karşılamaya yetmediğinde ise mühimmat yine aynı bölgeden ya da serbest piyasada faaliyet gösteren tüccardan satın alınarak karşılanmaktaydı. (Gündüz, 2012:201). 30 Ekim 1757 tarihinde Mehmet Kaptan'ın şaykasında görev yapan topçular ve dümencilerin 158 kuruş ücreti ile 22 kürekçinin y1llık ücreti olan 550 kuruş, Rusçuk cizyesi malından ocaklık olarak tayin edilmiştir.

\subsection{Silistre İskelesi Malları}

Mal alıp satan yerli ve yabancı tüccarlardan alınan vergilerden oluşan Silistre iskelesi malları mukataası Tuna donanmasının donatımında rol oynamaktaydı. Ocaklık usulüyle mal tahsisi burası için de geçerliydi. Örneğin 1763/1764 yılında Silistre şaykasında görev yapan 1 kaptan ve 20 kadar kürekçinin ulufe ve yemek masrafı için her sene 24,160 sağ akçe buradan ocaklık olarak tahsis edilmiştir ${ }^{74}$.

\footnotetext{
${ }^{73}$ BOA.C.BH.247.11465.1.1.

${ }^{74}$ BOA.C.BH.254.11735.1.1.
} 


\subsection{Niğbolu Adet-i Ağnam Mukataası Malları}

Ağnam koyun demek olup ganemin çoğuludur. Ağnam vergisi koyun, keçi ve deve gibi hayvanlardan alınan vergi olup, toplanması mukataa usulüyle gerçekleştirilmektedir. Konu bağlamında ise Tuna donanmasının inşa ve donanmasında ocaklık olarak kullanılan bir vergi türüdür. 1779/1780 yılında Vidin şaykasında görev yapan kaptan, dümenci ve topçular ile 22 kürekçinin toplam 778 kuruş tutan ücretleri buradan ocaklık olarak tahsis edilmiştir ${ }^{75}$.

\subsection{Niğbolu Cizyesi Malları}

Cizye gayri Müslimlerin askerlik hizmetinden muaf tutulmalarının karşılığında devletçe onlardan tahsil edilen verginin adıdır. Bu vergi İslam devletinin onlara sağlamış olduğu güvenlik hizmetinin karşıllğıdır. Balkanlar gayri Müslimlerin yoğun olarak yaşadığı yerlerin başında gelmektedir. Niğbolu cizyesi ya da tam adıyla "Niğbolu ve tevabii keferesi cizyesi malı", Tuna donanması için seferber edilen gelir kaynaklarından birisidir. Örneğin 1717/1718 yılında Tuna donanmasında görev yapan 80 kıta üstü açık gemilerin dümenci ve kürekçi ücretleri için 585 esedi kuruş Niğbolu cizyesi mallarından ödenmiştir ${ }^{76}$.

\subsection{Aydın Muhassıllık Malları}

Muhass1l, devlete ait vergileri tahsil etmekle görevli olan kimsedir. (Pakalın, 1983: 569). Onun görev sahasına ise muhassıllık adı verilmektedir. Aydın muhassıllığı da Osmanlı mali teşkilatı içinde kendine yer bulan bir birimin adıdır. Aydın Kazası'nın idari sınırları Aydın muhassıllığının sınırlarını oluşturmaktadır. Aydın'ın Tuna donanmasının donatımında rol alması buradaki canlı ticari hayatın bir sonucu olarak tahsil edilen vergilerin burada yüksek olmasıyla ve deniz yoluyla ulaşımın mümkün bulunmasıyla ilgili olmalıdır. Esasında Aydın'da üretilen pamuk ve pamuk ipliğinin Osmanlı donanmasının yelken bezi ihtiyacının karşılanması için Gelibolu, Boğazhisarları ve 1709'da İstanbul'da açılmış bulunan Bezhane'de kullanıldığı bilinmektedir. Tuna donanmasının donatımı bağlamında Aydın muhassıllığının ismi 1693/1694 tarihli bir belgede geçmektedir. Buna göre Tuna donanması için Tophane-i Âmire'de dökülecek topların masrafları için buradan para talep edilmiş ancak Aydın Muhassılı Seyyid Ahmet Paşa bu parayı göndermekte gecikme göstermiştir ${ }^{77}$.

\subsection{Müsadere Gelirleri}

Müsadere suç işleyen memurun ya da kamu görevlisinin malvarlığına devletçe el konulmasıdır. Osmanlı Devleti'nde bu uygulamaya bir tedbirden daha çok bir ceza olarak başvurulduğu anlaşılmaktadır. (Öğün, 2006:67). Bu alandaki uygulamaya tam olarak müsadere demek de mümkün değildir. Çünkü bu uygulamayı müsadereden ayıran husus, kişinin zimmet borcunu ödeyecek kadar malının haczedilmesi, borç kapandıktan sonra ise artan meblağın mirasçılarına iade edilmesiydi. Oysa müsaderede kişinin bütün mal varlığı devlete geçmekteydi. Yani aslında yapılan işlem, el koyma sonrası gerçekleştirilen bir haciz işlemidir.

Konu bağlamında böyle bir uygulamaya 29 Aralık 1691'de tesadüf edilmektedir. Buna göre Niğbolu Sancağında cizye tahsiline gönderilen Yusuf isminde bir memur elinde 74 yük 50,480 akçe para varken Belgrat'ta vefat etmiştir. Devlet bu alacağının tahsil edilmesini Tuna kaptanı Ali Paşa'ya emretmiş ve ne kadar akçe tahsil edilirse Tuna donanmasının masrafları için sarf edilmesini istemiştir. Ayrıca Rusçuk kadısına müteveffa Yusuf'un Rusçuk'ta bulunan varislerinin mahkeme huzuruna çıkarılarak sorgulanması ve Yusuf'un tüm mal varlığının ortaya çıkarılması emredilmiştir ${ }^{78}$.

\footnotetext{
${ }^{75}$ BOA.C.BH.259.11973.1.1. /19 Recep 1193 (2 Ağustos 1779)

${ }^{76}$ BOA.AE.SAMD.III.193.18648.1.1. /10 Safer 1130 (13 Ocak 1718)

${ }^{77}$ BOA.A.DVNS.MHM.d.103.27. /Evasıt Cemaziyülahır 1105 (Ocak/Şubat 1694)

${ }^{78}$ BOA.AE.SAMD.II.3.241.1.1. /8 Rebiyülahir 1103 (29 Aralık 1691)
} 


\section{Donatımda Karşılaşılan Sorunlar}

Tuna donanmasının donatımında merkezi yönetim ya da taşra yöneticilerinden kaynaklanan sorunlar eksik olmamıştır. Bu sorunların bir kısmı merkezi idarenin taşradaki imkânları zorlayan taleplerinden kaynaklanırken bir kısmı yerel yöneticilerin talep edilen malzemeleri zamanında temin edememesinden kaynaklanmış bir kısmı ise yeterli gelir kaynaklarının oluşturulamamasından ve donatılmış olan gemilerdeki mürettebatın başıbozukluğundan kaynaklanmıştır.

Tuna donanmasının inşa ve donatımı için gerekli olan malzemelerin zamanında ve tam olarak temin edilememesi bu sorunların başında gelmekteydi. Özellikle kereste temininde bu sorun 18. yüzyılda sıkça yaşanmaktaydı. Bu konuyla ilgili Eflak voyvodalarına bu dönemde birçok hüküm yazılmış ve talep edilen keresteyi Tuna kaptanlarına teslimde gevşeklik göstermemeleri emredilmiştir ${ }^{79}$. Osmanlı idari terminolojisinde "memleketeyn" olarak isimlendirilen Eflak ve Boğdan'ın bu yüzyılda yapılan Osmanl1-Rus savaşları sırasında cephe bölgesi haline gelmesi ve sıkça el değiştirmesi Eflak'ta bu türden sorunları büyütmüştür.

Gemi kaptanlarının ocaklık olarak kendilerine tahsis olunan gelirleri farklı nedenlerle alamamaları Tuna donanması gemilerinin donatımında sorun oluşturmaktaydı. Bu durumda gemi kaptanları borçlanarak gemilerini donatmakta ve yaptıkları harcamanın karşılığını devletten talep etmekteydi. Örneğin 1786/1787 yılında Fethülislam şaykası kaptanı Abdullah Kaptan, şaykasında görev yapan mürettebatın "taamiye", "ulufe" ve "kürekçi" ücretlerini Niğbolu mukataası kaleminden talep ettiğinde talebi kabul edilmemişti. O da borç almak suretiyle bu ücretleri ödemiş ardından görev yeri olan İsmail kazasındaki seraskerin emrine girmek için buraya hareket etmiştir. Bir süre sonra yapmış olduğu masrafi devletten talep etmişse de talebi serasker ya da başbuğları olan kaptanlar tarafindan böyle bir talepte bulunulmadığı gerekçesiyle geri çevrilmiştir ${ }^{80}$.

Levent yazımında gemi mürettebatının farklı bir gemiye yeniden yazılması sorun oluşturan bir konuydu. Çünkü fermanla kalyete ve firkatelere levent yazılacağı zaman levent olmak isteyen kimseye engel olunmaması istenmişken, donanma kalyonlarında görev yapan bazı kişilerin de levent yazıldığı ortaya çıkmıştı. Bu kişilerin yeni yazıldıkları gemilerde ayrıca ücret almaları bir tarafa bu mükerrer kayıt kalyonların mürettebat olarak zayıf kalmasına neden olmuştur ${ }^{81}$. Bu sorun donanmanın kışlağa çekildiği kasım-mart aralığındaki 6 aylık sürede yoğunlaşmaktaydı. Nedeni ise levent yazımına memur kişilerin usulsüzlükleri ve leventlerin bu altı aylık sürede başıboş kalmalarıydı. Esasında Osmanlı donanmasında mürettebatın kasım ayı geldiğinde çevreye dağılmadan mart ayına kadar kalacakları kışla ve binaların yapımı 18. yüzyılın sonlarına doğru Cezayirli Gazi Hasan Paşanın kaptan-1 deryalığına denk düşmektedir.

Gemi mürettebatından kaynaklanan sorunlar daha çok gemilerin savaşçı unsuru olan leventlerle ilgilidir. İnce donanma gemileri Tuna kıyısına yanaştıklarında bunların bir kısmı firar ederek hem kazalarda güvenlik sorunları oluşturmakta hem de donanma gemilerinin askeri yönden zayıflamasına neden olmaktaydılar. Leventlerin firar etmesinin sebebi ise gemilerdeki ağır çalışma koşulları, düşük ücretler ve yüksek yaralanma ve ya da ölüm riski olarak değerlendirilmektedir. Tuna donanması İstanbul'dan-Rusçuk'a giderken bu vakalar artmaktaydı. Bu durum leventlerin daha çok Anadolu ya da Doğu Akdeniz kökenli olmalarına da yorumlanabilir. Ancak leventlerin tamamı Anadolu ve Doğu Akdeniz kökenli olmayıp bir kısmı Balkan kökenlidir. Çünkü 1716/1717'da Ferhat Kaptan tarafindan yazılan 1000 kadar levendin 500 kadarı Yenipazar Kazası'ndan geri kalanı ise Dukakin Sancağı ile İpek ve Kosova gibi kazalardandır ${ }^{82}$. Leventlerin firarı aynı zamanda leventlikte liyakat, bilgi ve becerinin geri plana düştüğünü de göstermektedir.

\footnotetext{
${ }^{79}$ BOA.A.DVNS.MHM.d.101.11. /Evasıt Cemaziyülahır 1102 (Mart 1691).

${ }^{80}$ BOA.C.BH.197.9240.3.1. /16 Şevval 1201 (1 Ağustos 1787)

${ }^{81}$ BOA.İE.BH.6.504.1./12 Cemaziyülahır 1102 (13 Mart 1691)

${ }^{82}$ BOA.AE.SAMD.III.187.18081.1.1. $/ 25$ Ramazan 1129 (2 Eylül 1717)
} 
Devlet bu duruma önlem olarak ise İstanbul'dan Rusçuk'a varıncaya kadar olan kazaların kadılarına, yeniçeri serdarlarına, ayan-1 vilayet ve iş erlerine hükümler yazarak firar eden leventlerin yakalanmasını ve kaptanlarına teslim edilmesini emretmekteydi ${ }^{83}$.

\section{Sonuç}

Osmanlı Devleti 1353'te Balkanlara geçtikten sonra Tuna Nehri'nin kendisi açısından arz ettiği askeri, siyasi ve ticari önemi fark etmekte gecikmemiştir. Nehrin akış havzası onun Balkanlarda ilerlemesini kolaylaştırmış ve Orta Avrupa'ya kadar ilerleyerek Avrupa'nın önemli bir askeri gücü haline gelmeyi başarmıştır. Kili, İbrail, Akkirman, Silistre, Rahova, Varna ve Belgrad gibi Tuna nehri havzasındaki şehirlerin fethinden sonra Tuna Nehri'nde kendi seyir ve kullanım rejimini oluşturmuştur.

Osmanlılar Tuna Nehri'ni kara ordusunun Avrupa seferlerinde asker, erzak ve mühimmat naklinde, Belgrad, Fethülislam, Niş ve Silistre gibi önemli kalelerin tahkim edilmesinde, İstanbul'un iaşesinde ve ticari amaçlarla kullanmışlardır. Buna uygun olarak belli kazalarda tersaneler oluşturmuşlar Tuna nehrinde yüzebilecek özellikte şayka, firkate, kalyete ve tombaz türü gemiler inşa etmişlerdir. Nehir üzerinde güvenli geçişi için ise Girdap Ağalığı oluşturmuşlar ve ücreti karşı1lığında görevliler tayin etmişlerdir. Tuna Nehri’nin bu șekilde kullanımı Osmanlılardan önce Balkanlara hâkim olmuş olan Roma ve Bizans İmparatorluğu'nun kullanım şekline uygundur. Onlar da Tuna Nehrini aynı amaçlarla ve benzer usullerle kullanmışlardır. Osmanlıların onların bu tecrübelerinden istifade ettiklerinde şüphe yoktur.

Tuna donanmasının inşa ve donatımı için ihtiyaç duyulan malzemeler ve nitelikli işgücü öncelikle Tuna Nehrine komşu olan kazalardan karşılanmaya çalışılmıştır. Bu yeterli olmadığı zaman ise Tersane-i Âmire, Tophane-i Âmire ya da Cebehane-i Âmire gibi merkezi kamu kurumlarının kaynakları seferber edilmiştir. Esasında Tuna donanmasının talepleri, önemine binaen İstanbul tarafından geri çevrilmemiş, ihtiyaçlarının karşılanmasına azami özen gösterilmiştir. Osmanlı yönetiminin merkeziyetçi yapısı dolayısıyla Tuna donanmasıyla ilgili önemli kararlar İstanbul'dan verilmiştir.

Tuna donanmasının inşa ve donatımında merkezi yönetimin ve taşra yöneticilerinin gayretlerine rağmen sorunlar eksik olmamıştır. Bu sorunların başında ise gelir kaynaklarının yetersizliği, donatım malzemelerinin vaktiyle temin edilemeyişi ve gemi mürettebatının yeterince denetlenememesi gelmektedir. 18. yüzyılda yabancı devletlerle yapılan savaşların fazlalığı ve iç sorunlar bu sorunları daha da büyütmüştür. Ancak bu sorunlar merkezi yönetim tarafından yok sayılmamış ve çözülmesi için üzerine gidilmiştir. Bu sorunların tamamen çözüldüğünü söylemek mümkün değilse de ağır aksak çalışan sistemin 18. yüzyıl sonlarına kadar Tuna nehrinde Osmanlı Devletinin etkili bir güç olarak kalmasını sağladığı söylenebilir.

\section{Kaynakça}

\section{Bașbakanlık Osmanlı Arșivleri}

Ali Emiri-Sultan II. Ahmet Dönemi Belgeleri (AE.SAMD.II.): 3.

Ali Emiri-Sultan III. Ahmet Dönemi Belgeleri (AE.SAMD.III).: 187.

Ali Emiri-Sultan I. Mahmut Dönemi Belgeleri (AE.SMHD.I.): 104,106,181.

Ali Emiri-Sultan III. Selim Dönemi Belgeleri (AE.SSLM.III.): 116,136.

Cevdet Askeri (C.AS.): 996,1008.

${ }^{83}$ BOA.A.DVNS.MHM.d.101.9. /Evasıt Cemeziyülahir 1102 (Mart 1691) 
Cevdet Bahriye (C.BH.): 6, 15, 30, 41, 73, 101, 108, 111, 126, 130, 164, 174, 181, 186, 197, 202, 211, 215, 224, 237, 239, 247, 259, 263, 267, 254, 275.

Defterdar-Büyük Kale Kalemi (D.BKL.) :32663.

İbnülemin-Bahriye (İE.BH.): 6,7,10.

Mühimme Kalemi Defterleri, (A.DVNA.MHM.d.): 98, 99, 101, 102, 103, 104, 106.

Topkapı Sarayı (TS.MA.E.): 526.

Araștırma-İnceleme Eserler

Bostan, İ., (2012), Osmanlılar ve Deniz, Deniz Politikaları, Teşkilat Gemiler, Küre Yayınları, 3. Bask1, İstanbul.

Emecen, F., (2012), "Varna Muharebesi”, Türkiye Diyanet Vakfi İslam Ansiklopedisi, Cilt 42, İstanbul, 527-530.

Emecen, F., (2007), "Niğbolu Savaşı", Türkiye Diyanet Vakfi İslam Ansiklopedisi, Cilt 33, İstanbul, 89-92.

Gümüş, Ş. Ö., (2016), Sünne Boğazı'nda Seyrüsefer Güvenliği Ve Kule-İ Fener Vakfi, Akademik Sosyal Araştırmalar Dergisi 4(31), 35-52.

Grant, J., (2011), Osmanlı Gerilemesini Yeniden Düşünmek: Osmanlı Devleti'nde AskeriTeknolojinin Yeniden Yayılması (15. Yüzyıldan 18. Yüzyıla Kadar)”, Çeviren: Salim Aydüz, Yakın Dönem Türkiye Araştırmaları, Sayı 19-20, 57-79.

Gündüz, T., 2012, Osmanlı Teşkilat Tarihi El Kitabı, Grafiker Yayınları, Ankara.

Gürçay, L., (1962), Gemici Dili, Deniz Basımevi, İstanbul.

Öğün, T., 2006, "Müsadere", Türkiye Diyanet Vakfi İslam Ansiklopedisi, Cilt 32, TDV İslam Araştırmaları Merkezi, İstanbul, 67-68.

Pakalın, M. Z., 1983, Osmanlı tarih Deyimleri ve Terimleri Sözlüğü, Cilt I, 3. Baskı, Milli Eğitim Basımevi, İstanbul.

Pakalın, M. Z., 1983, Osmanlı tarih Deyimleri ve Terimleri Sözlüğü, Cilt II, 3. Bask1, Milli Eğitim Basımevi, İstanbul.

Pul, A., (2014), Osmanlı Tuna Donanmasının Üstüaçık Gemileri, Tarih Okulu Dergisi (TOD), Y11 7, Sayı XVIII, 285-317.

Schweigger, S., 2104, Sultanlar Kentine Yolculuk,1578-1581, Çeviren: Türkis Noyan, 2. Bask1, Kitap Yayınevi, İstanbul.

Uzunçarşıl1, İ. H.,1988Osmanlı Devleti'nin Merkez ve Bahriye Teşkilat1, Türk Tarih Kurumu Basımevi, Ankara.

Vakanüvist Subhi Mehmet Efendi, 2007, Suphi Tarihi, Hazırlayan: Mesut Aydıner, Kitabevi, İstanbul. 